\title{
Anaerobic methane oxidation in low-organic content methane seep sediments
}

\author{
John W. Pohlman ${ }^{\mathrm{a}, *}$, Michael Riedel ${ }^{\mathrm{b}, \mathrm{h}}$, James E. Bauer ${ }^{\mathrm{c}}$, Elizabeth A. Canuel ${ }^{\mathrm{d}}$, \\ Charles K. Paull ${ }^{\mathrm{e}}$, Laura Lapham ${ }^{\mathrm{f}}$, Kenneth S. Grabowski ${ }^{\mathrm{g}}$, Richard B. Coffin ${ }^{\mathrm{g}}$, \\ George D. Spence ${ }^{\mathrm{h}}$ \\ ${ }^{a}$ U.S. Geological Survey Woods Hole Coastal \& Marine Science Center, Woods Hole, MA, USA \\ ${ }^{\mathrm{b}}$ Geological Survey of Canada - Pacific, Sidney, BC, Canada \\ ${ }^{\mathrm{c}}$ Aquatic Ecology Laboratory, Department of Evolution, Ecology and Organismal Biology, The Ohio State University, Columbus, OH, USA \\ ${ }^{\mathrm{d}}$ Virginia Institute of Marine Science, College of William \& Mary, Gloucester Point, VA, USA \\ ${ }^{\mathrm{e}}$ Monterey Bay Aquarium Research Institute, Moss Landing, CA, USA \\ ${ }^{\mathrm{f}}$ Chesapeake Biological Laboratory, University of Maryland Center for Environmental Science, Solomons, MD, USA \\ ${ }^{\mathrm{g}}$ Naval Research Laboratory, Washington, DC, USA \\ ${ }^{\mathrm{h}}$ School of Earth and Ocean Sciences, University of Victoria, Victoria, BC, Canada
}

Received 8 February 2012; accepted in revised form 20 January 2013; available online 4 February 2013

\begin{abstract}
Sulfate-dependent anaerobic oxidation of methane (AOM) is the key sedimentary microbial process limiting methane emissions from marine sediments and methane seeps. In this study, we investigate how the presence of low-organic content sediment influences the capacity and efficiency of AOM at Bullseye vent, a gas hydrate-bearing cold seep offshore of Vancouver Island, Canada. The upper $8 \mathrm{~m}$ of sediment contains $<0.4 \mathrm{wt} . \%$ total organic carbon (OC) and primarily consists of glaciallyderived material that was deposited 14,900-15,900 yrs BP during the retreat of the late Quaternary Cordilleran Ice Sheet. We hypothesize this aged and exceptionally low-OC content sedimentary OM is biologically refractory, thereby limiting degradation of non-methane OM by sulfate reduction and maximizing methane consumption by sulfate-dependent AOM. A radiocarbon-based dissolved inorganic carbon (DIC) isotope mass balance model demonstrates that respired DIC in sediment pore fluids is derived from a fossil carbon source that is devoid of ${ }^{14} \mathrm{C}$. A fossil origin for the DIC precludes remineralization of non-fossil OM present within the sulfate zone as a significant contributor to pore water DIC, suggesting that nearly all sulfate is available for anaerobic oxidation of fossil seep methane. Methane flux from the SMT to the sediment water interface in a diffusion-dominated flux region of Bullseye vent was, on average, 96\% less than at an OM-rich seep in the Gulf of Mexico with a similar methane flux regime. Evidence for enhanced methane oxidation capacity within OM-poor sediments has implications for assessing how climate-sensitive reservoirs of sedimentary methane (e.g., gas hydrate) will respond to ocean warming, particularly along glacially-influenced mid and high latitude continental margins.
\end{abstract}

Published by Elsevier Ltd.

\footnotetext{
* Corresponding author. Tel.: +1 508457 2213; fax: +1 508457 2310.

E-mail addresses: jpohlman@usgs.gov (J.W. Pohlman), mriedel @nrcan.gc.ca (M. Riedel), bauer.362@osu.edu (J.E. Bauer), ecanuel@vims.edu (E.A. Canuel), paull@mbari.org (C.K. Paull), lapham@umces.edu (L. Lapham), ken.grabowski@nrl.navy.mil (K.S. Grabowski), rick.coffin@nrl.navy.mil (R.B. Coffin), gspence @uvic.ca (G.D. Spence).
}

\section{INTRODUCTION}

The sulfate-methane transition (SMT), the redox zone in methane-containing marine sediments where sulfate reduction is coupled to the anaerobic oxidation of methane (AOM), has been a subject of intense investigation for over four decades (Reeburgh, 1976; Alperin et al., 1988; Hoehler et al., 1994; Hinrichs et al., 1999; Boetius et al., 2000; 


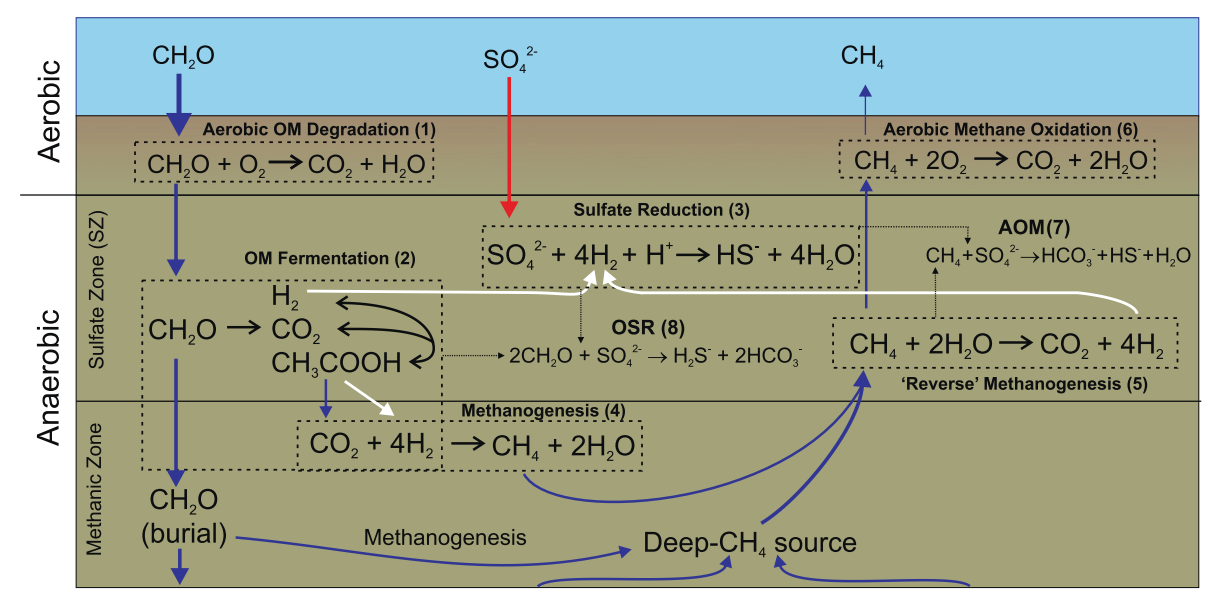

Fig. 1. Microbially-mediated carbon transformations in methane seeps. Organic matter $\left(\mathrm{OM}\right.$, represented as $\left.\mathrm{CH}_{2} \mathrm{O}\right)$ deposited on the seafloor is aerobically (1) and anaerobically (2) degraded to $\mathrm{CO}_{2}$, hydrogen $\left(\mathrm{H}_{2}\right)$ and smaller organic compounds (represented as acetate, $\mathrm{CH}_{3} \mathrm{COOH}$ ). Hydrogen produced during OM fermentation fuels sulfate reduction (3) and methanogenesis (4) in anaerobic sediments. Methane may be anaerobically oxidized by 'reverse' methanogenesis (5), aerobically oxidized (6) or emitted to the water column. The anaerobic oxidation of methane (AOM, 7) is the net reaction for sulfate reduction (3) and 'reverse methanogenesis' (5). Organoclastic sulfate reduction (OSR, 8) is the net reaction for sulfate reduction (3) and OM fermentation (2). Thin black arrows link the coupled redox reactions to the net reactions. Blue arrows $=$ carbon flux; red arrow $=$ sulfate flux; white arrows $=$ hydrogen flux. $\mathrm{mbsf}=$ meters below seafloor. (For interpretation of the references to colour in this figure legend, the reader is referred to the web version of this article.)

Alperin and Hoehler, 2009). Sulfate-dependent AOM is an oxidative process mediated by sulfate reducing bacteria and $A N$ aerobic $M E$ thane oxidizing archaea (ANME) (Eq. (1)) as

$\mathrm{SO}_{4}^{2-}+\mathrm{CH}_{4} \rightarrow \mathrm{HCO}_{3}^{-}+\mathrm{HS}^{-}+\mathrm{H}_{2} \mathrm{O}$

Consumption of methane by AOM in near-seafloor marine sediments significantly limits methane emissions from the seafloor. Reeburgh et al. (1993) estimated that nearly $90 \%$ of the $\sim 85 \mathrm{Tg} \mathrm{CH}_{4} \mathrm{yr}^{-1}$ produced globally in marine and freshwater systems is consumed before reaching the atmosphere, but did not delineate consumption by AOM. Hinrichs and Boetius (2002) utilized available AOM rate data and calculated that $\sim 382 \mathrm{Tg} \mathrm{CH}_{4} \mathrm{yr}^{-1}$ are consumed globally in continental margin sediments by AOM. This estimate is about five times the global methane consumption term estimated by Reeburgh et al. (1993) and equivalent to $\sim 60 \%$ of the net modern atmospheric methane flux (Kvenvolden and Rogers, 2005). As part of the global AOM budget, $78 \mathrm{Tg} \mathrm{CH}_{4} \mathrm{yr}^{-1}$ are consumed at methane seeps (Hinrichs and Boetius, 2002). Bowles et al. (2011b) calculate a substantially lower global seep AOM consumption rate of $3.5 \mathrm{Tg} \mathrm{CH}_{4} \mathrm{yr}^{-1}$, but that estimate is based on ex situ pressure incubations that yield rates 6-10 times slower than in situ pressure incubations (Bowles et al., 2011a).

Despite uncertainties in the global AOM budget, there is strong evidence that $\mathrm{AOM}$, in combination with aerobic oxidation in sediments (Sommer et al., 2006) and the overlying water column (Valentine et al., 2001), presently limits the ocean's contribution to $\sim 2 \%$ of the annual atmospheric methane flux (Reeburgh, 2007). However, methane mobilized from marine sediments may have been a more prominent component of the global carbon cycle during punctuated episodes in the geologic past (e.g., Dickens et al., 1995; Zachos et al., 2005). Additionally, if current trends in ocean warming continue (e.g., Westbrook et al., 2009; Biastoch et al., 2011), oceanic methane emissions may become increasingly important in the future, particularly at high-latitudes where climate warming is most pronounced. Therefore, a better understanding of the factors regulating methane release at cold seeps, the primary conduits for transmitting methane from the seafloor (Judd, 2004), is necessary to constrain the current and future global methane budget.

The primary energy source driving all microbially-mediated carbon transformations at methane seeps is OM deposited on the seafloor (represented as $\mathrm{CH}_{2} \mathrm{O}$ in Fig. 1). OM deposited at the sediment surface is initially degraded to carbon dioxide $\left(\mathrm{CO}_{2}\right)$ by aerobic respiration. Once oxygen is consumed, respiration proceeds by anaerobic processes. Within anaerobic sediments, fermentation of OM releases hydrogen and short-chain organic compounds that support organoclastic sulfate reduction (SR) in the sulfate zone (SZ) and methanogenesis at greater depths (Valentine, 2001). The thickness of the SZ in and around seeps is generally less than $\sim 10 \mathrm{~m}$ and frequently less than $1 \mathrm{~m}$, while the methanic zone extends $100 \mathrm{~s}$ of meters. Methane seeps are distinct from other ocean floor settings because tectonic forces and geologic conduits channel methane to the seafloor, supporting AOM rates that exceed non-seep sediments (Bowles et al., 2011b and references therein). When the methane flux exceeds the capacity of AOM (e.g., Niemann et al., 2006b), excess methane is either oxidized aerobically near the sedimentwater interface (Sommer et al., 2006) or emitted into the ocean. SR is coupled to OM degradation and AOM via interspecies hydrogen transfers. Thus, SR occupies a central role in the carbon cycle of methane seeps. How sulfate 

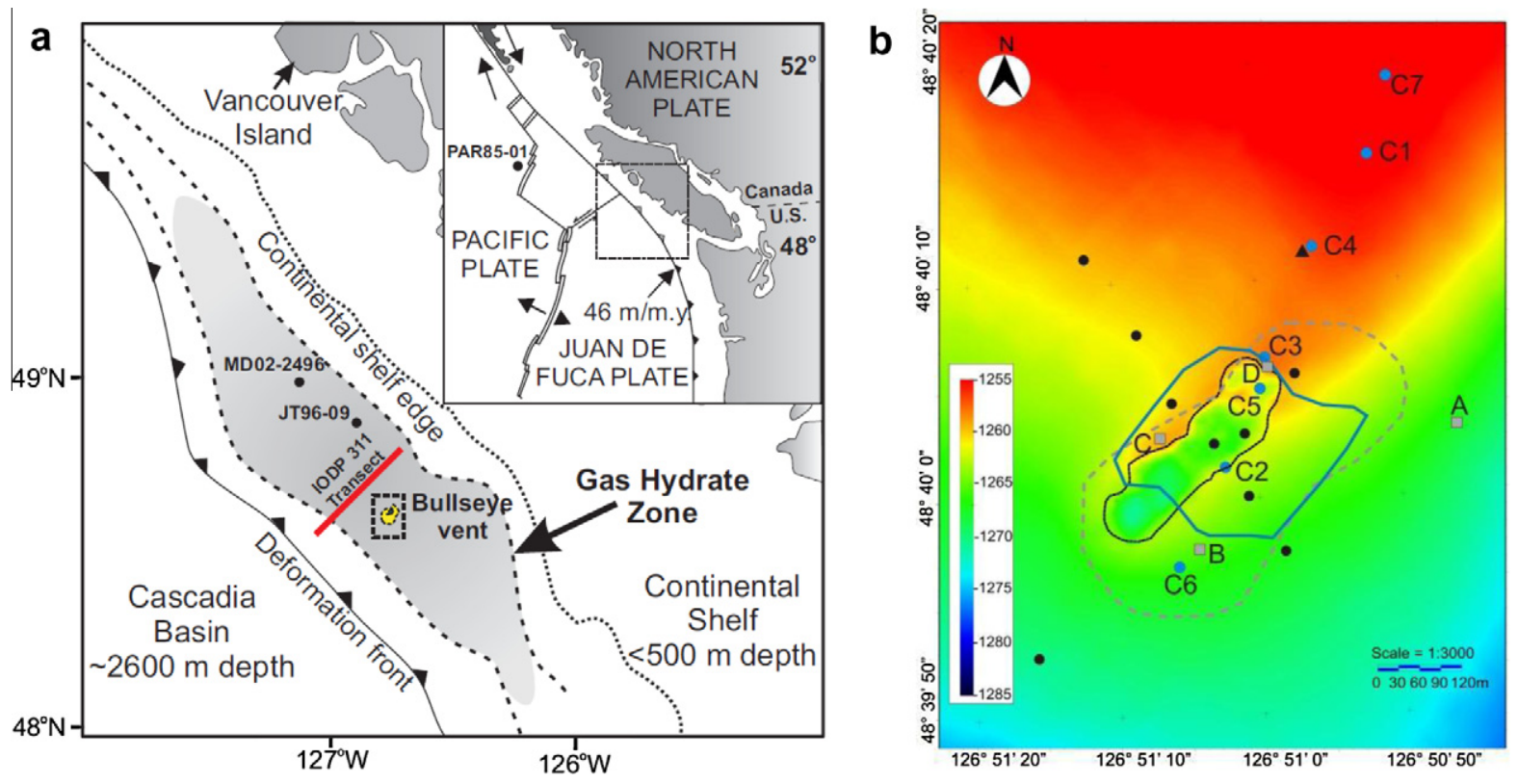

Fig. 2. Geographic setting of the northern Cascadia margin. (a) Bullseye vent is located $\sim 2 \mathrm{~km}$ from the Integrated Ocean Drilling Program Expedition 311 (IODP 311) transect and was the drilling location for the off-transect Site U1328. Gas hydrate has been inferred from bottom simulating reflectors (BSR) in the shaded area of the continental slope (Spence et al., 1991). Additional coring locations discussed in the text (JT96-09, McKay et al., 2004; MD02-2496, Cosma and Hendy, 2008; PAR85-01 (inset), Blaise et al., 1990) are included for reference. (b) Coring locations from PGC01-03 ( $\square$ ) and PGC02-08 (๑). Other piston cores taken in the area of Bullseye vent from previous studies are shown as black circles (Novosel et al., 2005; Riedel et al., 2006b) and black triangles (Briggs et al., 2011). The solid black line outlines the seafloor depression that defines the seep (Thomas et al., 2009). The dashed line is an area of gas-related seismic blanking, and the solid blue line is the area of a gas hydrate cap underlying the seep. The color bar on the left side of the panel indicates water depth, in meters. (For interpretation of the references to colour in this figure legend, the reader is referred to the web version of this article.)

is partitioned between the processes of $\mathrm{OM}$ oxidation and $\mathrm{AOM}$ is a key factor influencing how much methane may be consumed by AOM.

In the present study, we investigate how sedimentary OM bioavailability influences the biogeochemistry of Bullseye vent, a methane seep located on the glacially-influenced northern Cascadia margin offshore of British Columbia, Canada (Fig. 2). We demonstrate that the upper $8 \mathrm{~m}$ of sediment at Bullseye vent are comprised of low OM-content glacial-marine material deposited during the termination of the last glacial maximum. We hypothesize that Bullseye vent and methane seeps having similarly OM-poor sediment content allocate a smaller proportion of sulfate to the oxidation of sedimentary OM than OM-rich seep sediments with similar methane fluxes and electron acceptor availability. A radiocarbon-based mass balance model for pore water dissolved inorganic carbon (DIC) provides compelling evidence that remineralization of non-fossil OM by sulfate reduction is not a significant process in Bullseye vent sediments. Instead, production of pore water DIC is dominated by fossil carbon sources that most likely include methane, deeply buried sedimentary OM and dissolved organic carbon (DOC). These findings have implications for predicting how other glacially-influenced methane seeps and sediments may respond to enhanced methane emissions from climate-sensitive sedimentary methane reservoirs, including gas hydrate.

\section{SITE DESCRIPTION AND SLOPE SEDIMENTATION}

Bullseye vent, located on the continental margin offshore of Vancouver Island, Canada (Fig. 2a), is a seafloor depression located on a topographic high formed by thrust faulting within the northern Cascadia margin accretionary prism (Fig. 3a). The vent site is underlain by bedded sediments that gradually thin into the footwall side of uplifted thrust faults (Fig. 3a) (Riedel et al., 2002). The vent occurs above a $0.1 \mathrm{~km}^{2}$ seismic blanking feature indicative of free gas (dashed line in Fig. 2b) and a thick gas hydrate cap (solid blue line in Fig. 2a). Several of these features, described as 'chimneys,' are present along the inner margin of the landward thrust fault (Riedel et al., 2006b). Seismic blanking results from acoustic scattering associated with free gas, shallow carbonates or gas hydrate accumulations (Riedel et al., 2002; Wood et al., 2002; Zühlsdorff and Spieß, 2004). Gas hydrate recovered from Bullseye vent contains microbial methane with $\delta^{13} \mathrm{C}$ values that range from $-64.6 \%$ to $-63.2 \%$ and a near-fossil $\Delta^{14} \mathrm{C}$ value of $-985 \pm 2.6 \%$ (Pohlman et al., 2009). Methane constitutes at least $99.7 \%$ of the total hydrocarbons recovered from gas hydrate samples at this site (Pohlman et al., 2009).

Sediments from the upper 50 meters below the seafloor (mbsf) along the northern Cascadia margin are comprised of Late Pleistocene (10-50 ka BP) and Holocene-aged mate- 

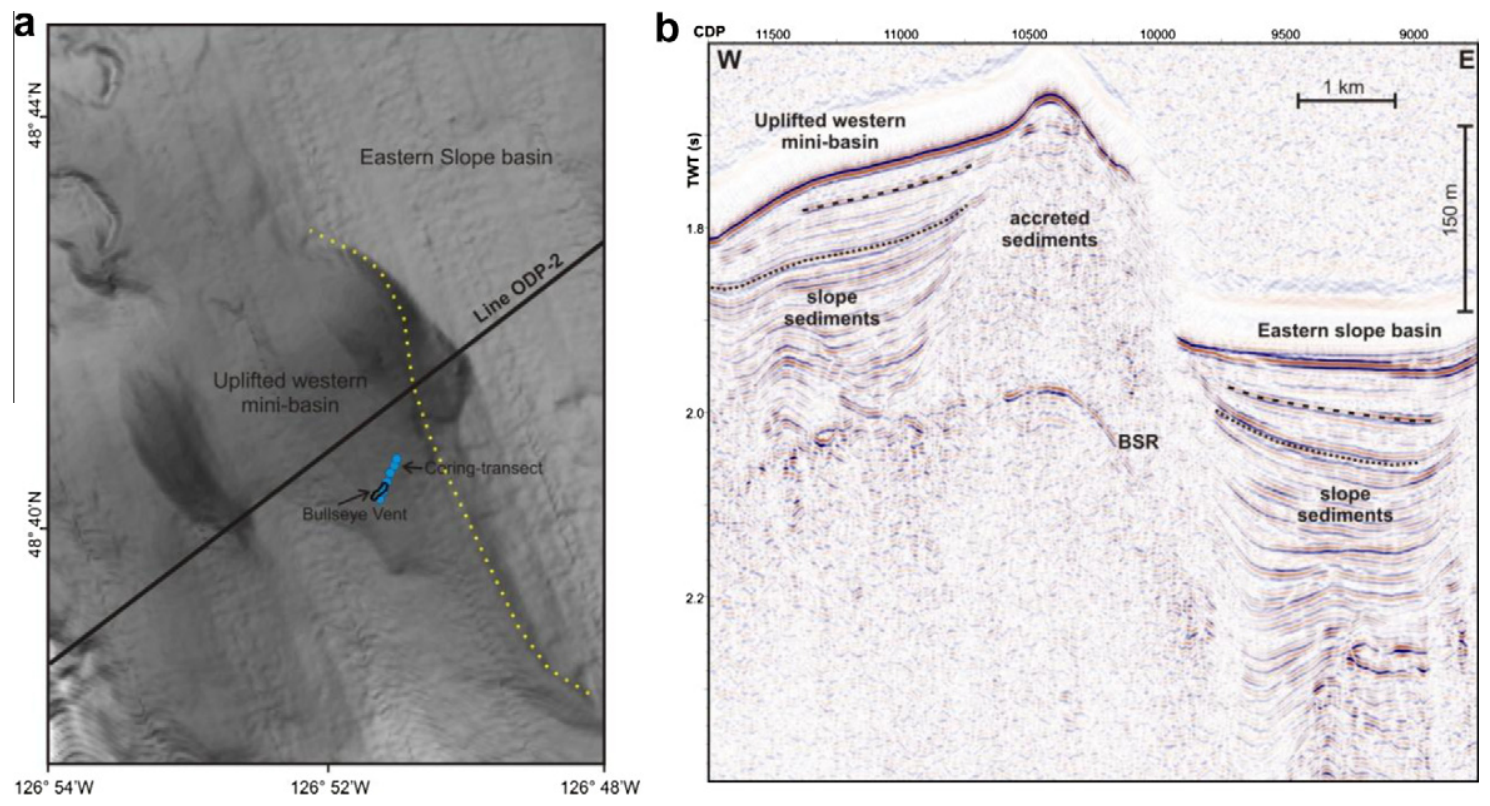

Fig. 3. Bullseye vent seepage area. (a) Black line indicates location of seismic reflection profile ODP-2 shown in panel B. Blue circles indicate location of piston cores used in this study. Dotted yellow line indicates location of $\sim 225 \mathrm{~m}$ high east facing escarpment which separates the mini-basin underlying Bullseye vent from the broad slope basin to the northeast. (b) Seismic reflection profile ODP-2 shows strong continuous reflections from the basin sediments. The escarpment is believed to be a fault scarp that vertically isolates the slope basin from the Bullseye area. The dashed lines indicate seismic reflections that may be of common stratigraphic origin. The bottom simulating reflector (BSR), an indication of free gas near the base of the gas hydrate stability zone, is evident beneath the uplifted mini-basin and the accreted ridge, but is more difficult to identify beneath the slope basin. TWT (s): two way travel time, in seconds. (For interpretation of the references to colour in this figure legend, the reader is referred to the web version of this article.)

rial ( $<10 \mathrm{ka}$ BP) (Carson et al., 1995; McKay et al., 2004; Riedel et al., 2006a; Cosma and Hendy, 2008; Akiba et al., 2009). Late Pleistocene sedimentation along the northern Cascadia margin was dominated by glacial-marine sediment transport and deposition during the advance and retreat of the Cordilleran Ice Sheet (Bornhold and Barrie, 1991; Cosma and Hendy, 2008). As the ice sheet advanced and subsequently retreated from $\sim 30 \mathrm{ka}$ BP until $\sim 10$ ka BP, terrestrial organic and lithogenic material was rapidly deposited (up to $463 \mathrm{~cm} \mathrm{ka}^{-1}$ ) on the continental slope (McKay et al., 2004; Cosma and Hendy, 2008). At the termination of glaciation during the Bølling-Allerød interstadial ( $\sim 14.7 \mathrm{ka} \mathrm{BP})$ and continuing throughout the Holocene, marine primary production increased and sediment with organic matter of marine origin has accumulated, albeit at greatly reduced rates $\left(\sim 5 \mathrm{~cm} \mathrm{ka}^{-1}\right)$ (McKay et al., 2004).

\section{METHODS}

\subsection{Sample collection and processing}

Sediment piston cores for this study were obtained during cruises PGC01-03 and PGC02-08 on board the CCGS John P. Tully. Four cores (identified as A, B, C and D in Fig. 2b) were collected during cruise PGC01-03. Data reported from these four cores are limited to sulfate concentrations and sulfate reduction rates. During PGC02-08, seven cores were collected along an $850 \mathrm{~m}$ transect that crosses Bullseye vent and extends upslope toward the eastern slope basin (Fig. 2b, Table 1). Core 5 was collected from within the depression of the vent site where gas hydrate is present and chemosynthetic biological communities are living at the seafloor (Riedel et al., 2006b). Cores 2 and 3 are from the edge of the depression and overlie the acoustically defined gas hydrate cap (solid blue line in Fig. 2b) and a zone of seismic blanking (dashed grey line in Fig. 2b), which has been associated with underlying free gas (Riedel et al., 2002; Wood et al., 2002; Zühlsdorff and Spieß, 2004). Core 6 was also collected from above the seismic blanking zone, but not above the hydrate cap. Cores 4,1 and 7 extend from 150 to $450 \mathrm{~m}$ away from the seep down the anticline of the accreted ridge.

Samples for methane concentration measurements were collected at $3 \mathrm{~cm}$ intervals as $2 \mathrm{~cm}^{3}$ sediment plugs and stored in $20 \mathrm{~mL}$ serum vials sealed with 1 -cm-thick butyl rubber septa. Pore waters were extracted by pressure-squeezing ( $\sim 3$ bar) and were filter-sterilized with $0.45 \mu \mathrm{m}$ acrodisc polyethersulphone (PES) syringe filters (Pall Corporation). Sediment samples for radiocarbon analysis were collected from samples adjacent to those processed for pore water analysis. Higher resolution solid phase elemental and stable carbon isotope vertical profiles (25-40 cm intervals) were obtained from the sediment processed for pore water extraction. Sediment samples were freeze-dried and split into fractions for isolation of foraminifera and analysis of TOC and bulk carbonate. The sediment samples for foraminifera were disaggregated by sonication for $1 \mathrm{~h}$ in a dilute Calgon $\odot$ 
Table 1

Piston core locations and information from Cruise PGC02-08.

\begin{tabular}{llll}
\hline Station & Latitude $(\mathrm{N})$ & Longitude $(\mathrm{W})$ & Water depth $(\mathrm{m})$ \\
\hline PGC02-08-01 (C1) & $48^{\circ} 40.2530^{\prime}$ & $126^{\circ} 50.8650^{\prime}$ & 1274 \\
PGC02-08-02 (C2) & $48^{\circ} 40.0146^{\prime}$ & $126^{\circ} 51.0389^{\prime}$ & 1282 \\
PGC02-08-03 (C3) & $48^{\circ} 40.0983^{\prime}$ & $126^{\circ} 50.9898^{\prime}$ & 1276 \\
PGC02-08-04 (C4) & $48^{\circ} 40.1829^{\prime}$ & $126^{\circ} 50.9317^{\prime}$ & 7.95 \\
PGC02-08-05 (C5) & $48^{\circ} 40.0744^{\prime}$ & $126^{\circ} 50.9961^{\prime}$ & 8.25 \\
PGC02-08-06 (C6) & $48^{\circ} 39.9388^{\prime}$ & $126^{\circ} 51.0953^{\prime}$ & 1282 \\
PGC02-08-07 (C7) & $48^{\circ} 40.3125^{\prime}$ & $126^{\circ} 50.8405^{\prime}$ & 1284 \\
\hline
\end{tabular}

solution and the $>125 \mu \mathrm{m}$ size fraction was rinsed and separated by wet sieving. After drying for $24 \mathrm{~h}$ at $50{ }^{\circ} \mathrm{C}, 7-10 \mathrm{mg}$ of mixed planktonic foraminifera (primarily Neogloboquadrina spp. and Globigerinoides spp., the dominant species in the study area for the past $50 \mathrm{ka}$ (Kennett and Ingram, 1995)) were handpicked. Bulk samples for TOC and carbonate measurements were ground with mortar and pestle and stored in glass vials until analyzed.

\subsection{Pore water analyses}

Dissolved concentrations of methane, sulfate and DIC, and stable carbon isotopes of DIC were measured as described by Pohlman et al. (2008). Briefly, methane concentrations were determined by the headspace equilibration technique and gas-chromatography (GC) flame-ionization detection using a Shimadzu GC 14-A. Sulfate concentrations were measured by ion chromatography using a Dionex DX-120 ion chromatograph equipped with a $4 \mathrm{~mm}$ AS-9HC column. DIC concentrations were determined coulometrically using a model 5011 UIC carbon dioxide coulometer. The stable carbon isotope composition of pore water DIC was measured using a Thermo Finnigan Delta S isotope ratio mass spectrometer (IRMS). Stable carbon isotope values are reported relative to Vienna PeeDee Belemnite (VPBD) in the standard $\delta$-notation.

\subsection{Bulk sediment analyses}

The stable carbon isotopic composition $\left(\delta^{13} \mathrm{C}\right)$ of the TOC and bulk carbonate was determined with a Thermo Finnigan Delta Plus XP IRMS. Prior to isotope analysis, TOC samples were weighed in silver cups with a microbalance, acidified with $10 \% \mathrm{HCl}$ to remove carbonate, dried at $50{ }^{\circ} \mathrm{C}$ for $24 \mathrm{~h}$ and then combusted on-line with a Fisons EA-1100 Elemental Analyzer (EA) interfaced to the IRMS. Samples for bulk carbon stable carbon isotopes were prepared for IRMS analysis by injecting $200-\mu 1$ of $85 \%$ phosphoric acid saturated with $\mathrm{CuSO}_{4}$ (to precipitate sulfides) into $2 \mathrm{~mL}$ serum vials containing approximately $0.2 \mathrm{~g}$ sediment. After heating the vials at $50^{\circ} \mathrm{C}$ for $24 \mathrm{~h}$, headspace gas from the vials was injected into a Thermo Finnigan Trace gas chromatograph (GC) where gases were separated isothermally $\left(50^{\circ} \mathrm{C}\right)$ on a Poraplot-Q capillary column ( $30 \mathrm{~m}, 0.32 \mathrm{~mm}$ ID) and then transferred to the IRMS through an open split. The ${ }^{13} \mathrm{C} /{ }^{12} \mathrm{C}$ ratios are expressed in conventional $\delta$-notation relative to the VPDB standard.
The total peak area from masses 44 and 45, normalized to an acetanilide standard, was used to calculate the TOC concentration.

\subsection{Radiocarbon sample preparation and analysis}

Foraminfera and bulk carbonate were converted to $\mathrm{CO}_{2}$ in an evacuated quartz carbonate digester by adding a solution of $85 \% \mathrm{H}_{3} \mathrm{PO}_{4}$ saturated with $\mathrm{CuSO}_{4}$ to dissolve the carbonate and precipitate sulfides evolved during the digestion/extraction process (Boehme et al., 1996). DIC was extracted as $\mathrm{CO}_{2}$ from pore water samples by adding $1 \mathrm{~mL}$ of a $10 \% \mathrm{H}_{3} \mathrm{PO}_{4}$ solution saturated with $\mathrm{CuSO}_{4}$ into the serum vials and stripping the solution with UHP He for $30 \mathrm{~min}$. Sediment for TOC analysis was acidified with a $10 \%$ solution of $\mathrm{HCl}$ to remove inorganic carbon, rinsed thoroughly with distilled water, freeze dried and then placed in $1 / 4^{\prime \prime} \mathrm{Vy}$ cor@ tubes with $\sim 200 \mathrm{mg}$ copper oxide and a grain of silver. The tubes were evacuated and placed in a $900{ }^{\circ} \mathrm{C}$ muffle furnace for $6 \mathrm{~h}$ to convert sedimentary $\mathrm{OM}$ to $\mathrm{CO}_{2}$ (Pohlman et al., 2000).

Carbon dioxide from bulk carbonate, foraminifera, DIC and TOC samples was purified cryogenically by a series of vacuum distillations using the radiocarbon sample distillation and graphite preparation system described by Pohlman et al. (2000). Approximately $1 \mathrm{mg}$ of sample carbon, as purified $\mathrm{CO}_{2}$, was transferred into graphite production reactors. The remaining $\mathrm{CO}_{2}$ from the foraminifera, bulk carbonate and TOC samples was collected in Vycor@ tubes and analyzed by dual-inlet IRMS. $\delta^{13} \mathrm{C}$ values for four foraminifera samples lost during shipping were estimated by regression analysis of paired foraminifera and bulk carbonate samples from Table $2\left(r^{2}=0.97 ; P<0.001 ; n=6\right)$. For radiocarbon analyses, the $\mathrm{CO}_{2}$ from each sample was catalytically reduced to graphite with hydrogen and $3 \mathrm{mg}$ of iron at $600{ }^{\circ} \mathrm{C}$ for $6 \mathrm{~h}$ (Vogel et al., 1984; Pohlman et al., 2000).

Graphite targets were analyzed for radiocarbon at the Naval Research Lab (NRL) accelerator mass spectrometry (AMS) facility. The NRL AMS is a 3 MV Pelletron tandem accelerator with an MC-SNICS ion source (Grabowski et al., 2000). All radiocarbon results include fully propagated internal errors from samples, standards and blanks (Tumey et al., 2004). In this study, the $\mathrm{D}^{14} \mathrm{C}$ notation is used for calculating conventional radiocarbon ages (Stuiver and Polach, 1977) and when performing mass balance corrections that account for precipitation of methane 


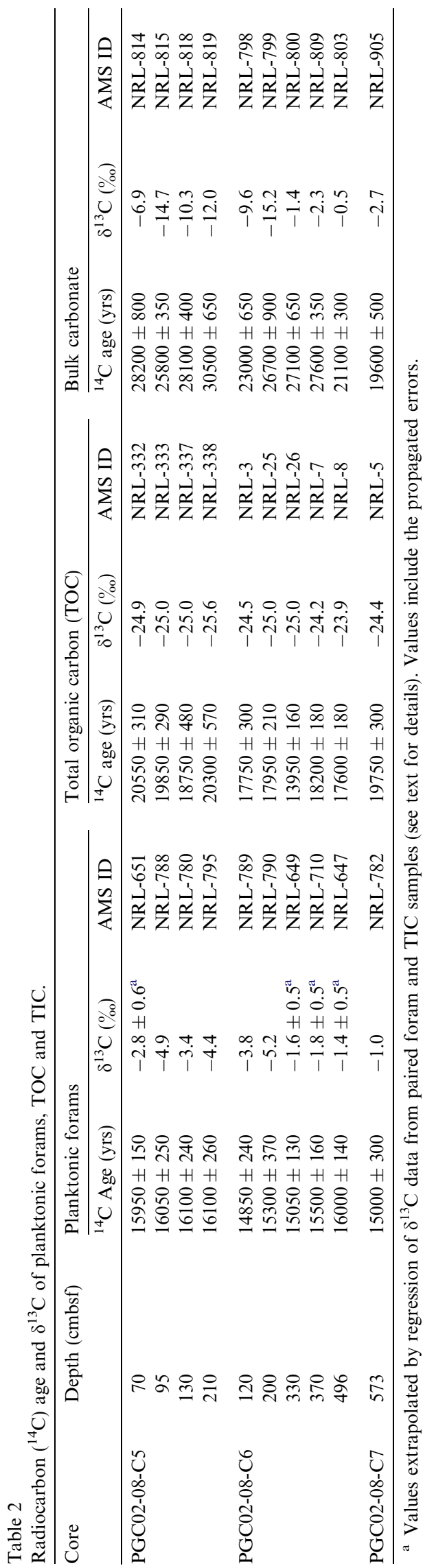

derived authigenic carbonates on the foraminifera (see Section 5.2.2). The mass balance-corrected foraminifera results are converted to calendar years using the CALIB 5.0 program (Stuiver and Reimer, 1993) with the Marine04 calibration dataset (Hughen et al., 2004) and a reservoir correction of $1100 \pm 200 \mathrm{yrs}$ (Kienast and McKay, 2001). The $\Delta^{14} \mathrm{C}$ notation, which differs slightly from the $\mathrm{D}^{14} \mathrm{C}$ notation in that it has been corrected for decay of the oxalic acid standard since 1950 (Stuiver and Polach, 1977), is utilized for the DIC radiocarbon isotope mass balance model.

\subsection{Sulfate reduction rates}

Sulfate reduction rates in Bullseye vent sediments were determined using a shipboard radioisotope incubation procedure where ${ }^{35} \mathrm{~S}$-labelled sulfide produced during biological reduction of ${ }^{35} \mathrm{~S}$-labelled sulfate is measured by scintillation counting (Albert et al., 1995), which is a modification of the standard technique by Jørgensen (1978). The measurement was conducted on samples from sediment cores A, B, C and D collected during cruise PGC01-03 (Fig. 2b). Briefly, $3 \mathrm{~mL}$ sediment plugs collected in glass syringes were sealed with rubber septa and incubated with a $10 \mu \mathrm{l}$ aliquot of $1 \mu \mathrm{Ci}{ }^{35} \mathrm{~S}$ labeled sodium sulfate that was line injected through the septa. The sediment plugs were incubated at in situ $\left(1^{\circ} \mathrm{C}\right)$ temperature for $\sim 24 \mathrm{~h}$. Following incubation, sediments were dispensed into $100-\mathrm{mL}$ glass serum vials containing $3-\mathrm{mL}$ of $0.1 \mathrm{M}$ sodium sulfide to overwhelm reactions that might oxidize the ${ }^{35} \mathrm{~S}$-labeled sulfide. 3-mL of $0.5 \mathrm{M}$ zinc acetate was added to stabilize sulfide in the form of insoluble zinc sulfide and 3-mL of $0.1 \mathrm{M}$ sodium hydroxide was added to terminate biological activity. The vials were sealed with butyl rubber stoppers and stored frozen until further analysis. Sulfate reduction rates $\left(\mathrm{nmol} \mathrm{cm} \mathrm{cm}^{-3} \mathrm{~d}^{-1}\right)$ were calculated as:

$\mathrm{SR}$ rate $=\left[\mathrm{SO}_{4}^{2-}\right] \cdot \frac{\phi \cdot \alpha}{t} \cdot \frac{\mathrm{H}_{2}{ }^{35} \mathrm{~S}}{{ }^{35} \mathrm{SO}_{4}^{2-}(\text { added })}$

where $\left[\mathrm{SO}_{4}^{2-}\right]$ is the pore water sulfate concentration $\left(\mathrm{nmol} \mathrm{cm}{ }^{-3}\right), \phi$ is sediment porosity, $\alpha$ is the fractionation factor (1.04, Jørgensen, 1978), $t$ is the incubation time (in days), $\mathrm{H}_{2}{ }^{35} \mathrm{~S}$ is the radioactivity of sulfide determined by an acidic chromium reduction method (Albert et al., 1995) and ${ }^{35} \mathrm{SO}_{4}^{2-}$ (added)' is radioactivity of the radioisotope added to the incubation. The limit of detection is $0.2 \mathrm{nM} \mathrm{d}^{-1}$. All depths were run in duplicate, and the standard deviation of these duplicates ranged from 9 to $78 \mathrm{nM} /$ day.

\subsection{Diffusive methane fluxes}

Diffusive methane fluxes from the SMT to the sediment water interface (SWI) were calculated according to Fick's first law (Berner, 1980) as:

$J=-\phi \cdot D_{s} \cdot \frac{\mathrm{d} C}{\mathrm{dz}}$

where $J$ is the diffusive flux $\left(\mu \mathrm{mol} \mathrm{m}{ }^{-2} \mathrm{yr}^{-1}\right), \phi$ is the average sediment porosity above the $\operatorname{SMT}(0.7), D_{\mathrm{s}}$ is the sediment diffusion coefficient for methane $\left(0.50 \times 10^{-5} \mathrm{~cm}^{2} \mathrm{~s}^{-1}\right)$ corrected for temperature and porosity effects (Iversen and 


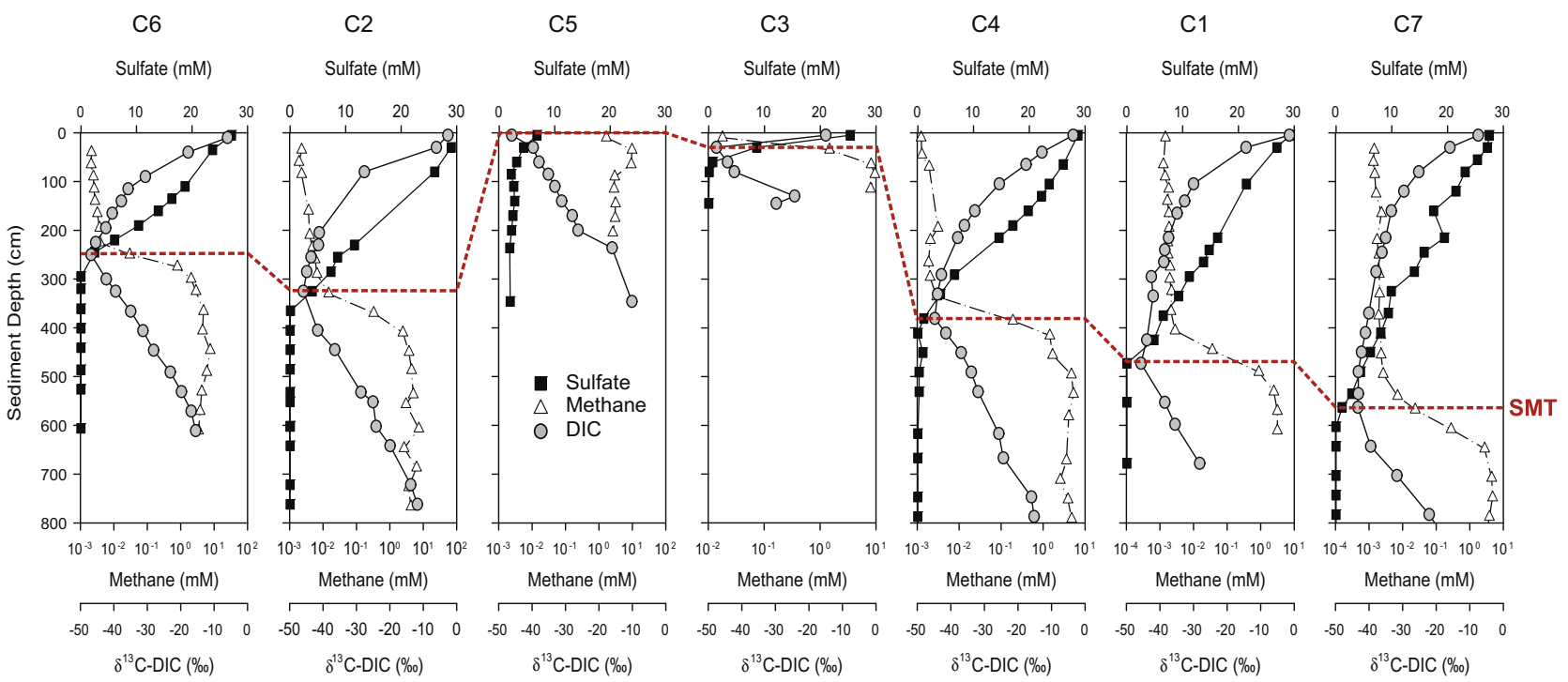

Fig. 4. Sediment pore water profiles of sulfate concentration $(\square)$, methane concentration $(\triangle)$ and $\delta^{13} \mathrm{C}$ of dissolved inorganic carbon (DIC) (O). The profile panels are oriented in relation to their position along the coring transect from cruise PGC02-08 (see Fig. 2b). The dashed red line denotes the depth of the sulfate-methane transition (SMT).

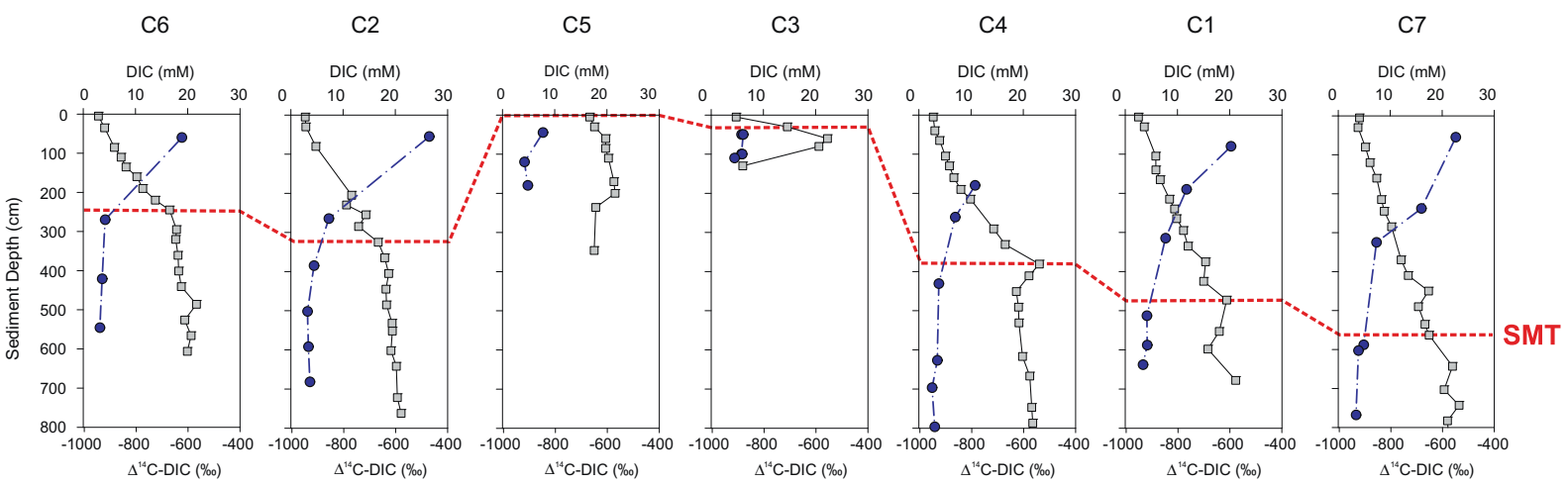

Fig. 5. Sediment pore water profiles of dissolved inorganic carbon (DIC) concentration $(\square)$ and $\Delta{ }^{14} \mathrm{C}(\boldsymbol{)})$. The profile panels are oriented in relation to their position along the coring transect from cruise PGC02-08 (see Fig. 2b). The dashed red line denotes the depth of the sulfatemethane transition (SMT), as determined from the $\delta^{13} \mathrm{C}$-DIC minima identified in Fig. 4.

Jørgensen, 1993), $C$ is the pore water concentration of methane $\left(\mu \mathrm{mol} \mathrm{L}{ }^{-1}\right)$ between the SMT and the sediment water interface, and $z$ is sediment depth (cmbsf).

\section{RESULTS}

\subsection{Pore water geochemical profiles}

In general, sulfate concentrations decrease with depth to the SMT, while methane concentrations increase with depth below the SMT (Fig. 4). With the exception of Core 5, where sulfate concentrations average $2.6 \pm 0.8 \mathrm{mM}$ $(n=9)$ throughout, sulfate concentrations decrease from seawater values $(\sim 29 \mathrm{mM})$ near the seafloor to values generally $<0.1 \mathrm{mM}$ below the SMT (Fig. 4). Methane concentrations range from 0.001 to $0.018 \mathrm{mM}$ above the SMT and increase dramatically near and below the SMT (Fig. 4). Including Core 5, which was collected at an active seep, methane concentrations below the SMT range from 0.3 to $9.7 \mathrm{mM}$. However, because the solubility of methane at 1 bar and $4{ }^{\circ} \mathrm{C}$ is $\sim 1.8 \mathrm{mM}$ (Yamamoto et al., 1976), the samples from below the SMT likely lost methane during core recovery and sampling.

Dissolved inorganic carbon concentrations increase from seawater values $(\sim 2.4 \mathrm{mM})$ near the seafloor to concentrations that range from 14.5 to $23.0 \mathrm{mM}$ at the SMT (Fig. 5). Below the SMT, DIC concentrations generally remain constant or increase slightly with increasing depth. Minimum $\delta^{13} \mathrm{C}$-DIC values occur at the SMT, ranging from $-47.5 \%$ to $-43.3 \%$ (Fig. 4 ). $\delta^{13} \mathrm{C}$ values of DIC increase with distance from the SMT (both upcore and downcore) in all cores (Fig. 4) except for Core 5, where the SMT is at the seafloor. The $\Delta^{14} \mathrm{C}$-DIC values above the SMT $(-860 \%$ to $-470 \%)$ are highest near the seafloor and decrease with depth to the SMT (Fig. 5, see Electronic Annex for actual values). The $\Delta^{14} \mathrm{C}$-DIC values below the SMT 


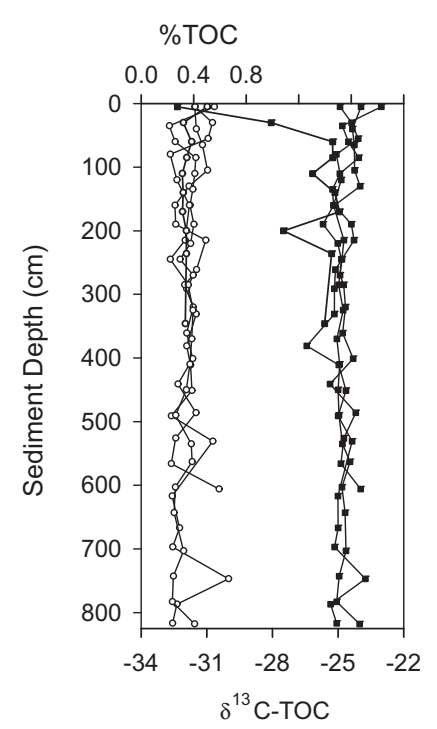

Fig. 6. Total organic carbon (TOC) concentration $(-)$ and $\delta^{13} \mathrm{C}$ $(\rightarrow)$ profiles. The profiles are not distinguished by location to illustrate the general uniformity of the values in the vertical and horizontal dimensions. All of the ${ }^{13} \mathrm{C}$-depleted $\mathrm{TOC}$ values are from Core 5, which contained gas hydrate and had the shallowest SMT (Fig. 4).

$(-949 \%$ to $-844 \%$ oo are consistently lower and decrease slightly with increasing depth.

\subsection{TOC and bulk carbonate concentration and $\delta^{13} \mathrm{C}$}

The $\delta^{13} \mathrm{C}$ and wt.\% of TOC are relatively uniform with depth throughout all of the cores (Fig. 6). All but three of the 74 samples analyzed for $\delta^{13} \mathrm{C}$-TOC range from $-26.4 \%$ to $-23.0 \%$ and the overall average is $-24.5 \pm 0.5 \%$. The outlier values (all from the seep Core 5) range from -32.3 to $-28.1 \%$. The wt. $\%$ TOC ranges from $0.22 \%$ to $0.67 \%$ and averages $0.36 \pm 0.10 \mathrm{wt} . \%$ (Fig. 6). $\delta^{13} \mathrm{C}$ values of the bulk carbonate range from $+2.5 \%$ to $-27.0 \%$ with an average value of $-6.0 \pm 5.8 \%$ o (Fig. 7).

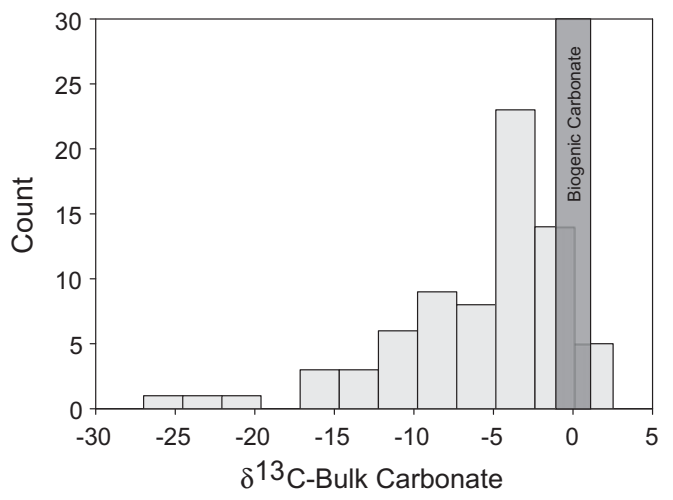

Fig. 7. Frequency histogram of $\delta^{13} \mathrm{C}$ of bulk carbonate from all cores investigated. The shaded area represents the regional range for biogenic carbonate (Ortiz et al., 1996).
4.3. Radiocarbon age and $\delta^{13} \mathrm{C}$ of planktonic foraminifera, TOC and bulk carbonate

Average radiocarbon $\left({ }^{14} \mathrm{C}\right)$ ages of the planktonic foraminifera, TOC and bulk carbonate are 15,600 \pm 500 , $18,460 \pm 1920$ and $25,750 \pm 3450{ }^{14} \mathrm{C}$ yr BP, respectively (Table 2; Fig. 8). The sediment profiles do not display obvious age relationships with depth. However, the ages among the different sediment components are distinct. In nearly all cases, the radiocarbon age of planktonic foraminifera is youngest, the TOC is intermediate in age and bulk carbonate is oldest (Fig. 8). Average $\delta^{13} \mathrm{C}$ values for the planktonic foraminifera, TOC and bulk carbonate samples analyzed for radiocarbon are $-3.3 \pm 1.4 \%,-24.8 \pm 0.5 \%$, and $-8.1 \pm 5.6 \%$, respectively (Table 2 ).

\subsection{Ex situ sulfate reduction rates}

The four cores from Cruise PGC03-01 were measured for sulfate concentrations (Fig. 9a) and sulfate reduction rates (Fig. 9b). Sulfate concentrations for Cores A and B (located outside the gas hydrate cap, Fig. 2b) are near those of overlying seawater $(28 \mathrm{mM})$ and decrease to $\sim 2 \mathrm{mM}$ by $400 \mathrm{cmbsf}$ (Fig. 9a), where the SMT is inferred to reside. Sulfate reduction rates for Core A are $2.1-2.2 \mathrm{nmol} \mathrm{cm}^{-3} \mathrm{~d}^{-1}$ within the upper $200 \mathrm{~cm}$ and $0.25 \mathrm{nmol} \mathrm{cm}^{-3} \mathrm{~d}^{-1}$ at $300 \mathrm{~cm}$ (Fig. 9b). For Core B, rates are $1.7-2.5 \mathrm{nmol} \mathrm{cm}^{-3} \mathrm{~d}^{-1}$ within the top $100 \mathrm{cmbsf}$, and $3.0 \mathrm{nmol} \mathrm{cm} \mathrm{c}^{-3} \mathrm{~d}^{-1}$ near or within the SMT (452 cmbsf) (Fig. 9b). Below the SMT in Cores A and $B$, sulfate reduction rates are $0.35 \mathrm{nmol} \mathrm{cm} \mathrm{cm}^{-3} \mathrm{~d}^{-1}$ or less. Sulfate concentrations for Cores C and D (located beneath the gas hydrate cap) are $\leqslant 6 \mathrm{mM}$ at all depths (Fig. 9a). The SMT depth for these cores is likely less than $1 \mathrm{mbsf}$. Sulfate reduction rates in Cores $\mathrm{C}$ and $\mathrm{D}$ are $\leqslant 1.4 \mathrm{nmol} \mathrm{cm}^{-3} \mathrm{~d}^{-1}$ (Fig. 9b) with an average rate of $0.4 \mathrm{nmol} \mathrm{cm}{ }^{-3} \mathrm{~d}^{-1}$.

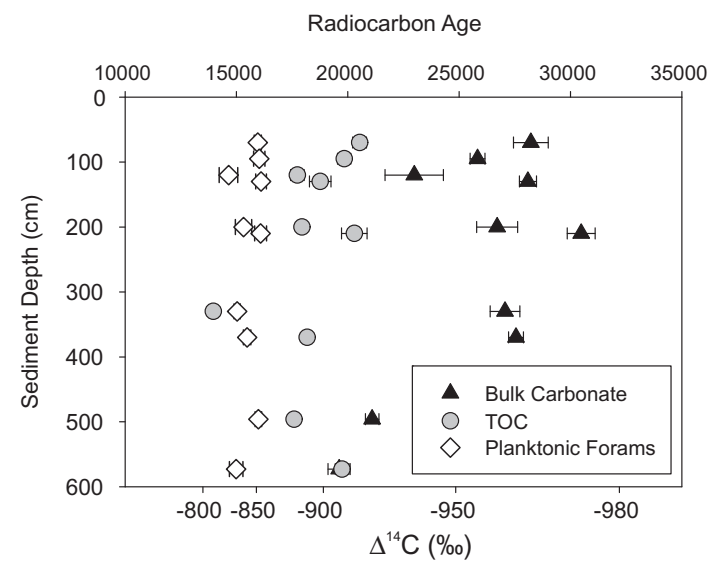

Fig. 8. Radiocarbon $\left({ }^{14} \mathrm{C}\right)$ age and $\Delta^{14} \mathrm{C}$ comparison of bulk carbonate, total organic carbon (TOC) and planktonic foraminifera from paired samples collected at the Bullseye vent site (see Table 2 for data). The horizontal bars indicate the propagated analytical errors. Where absent, the error is less than the size of the symbol. 

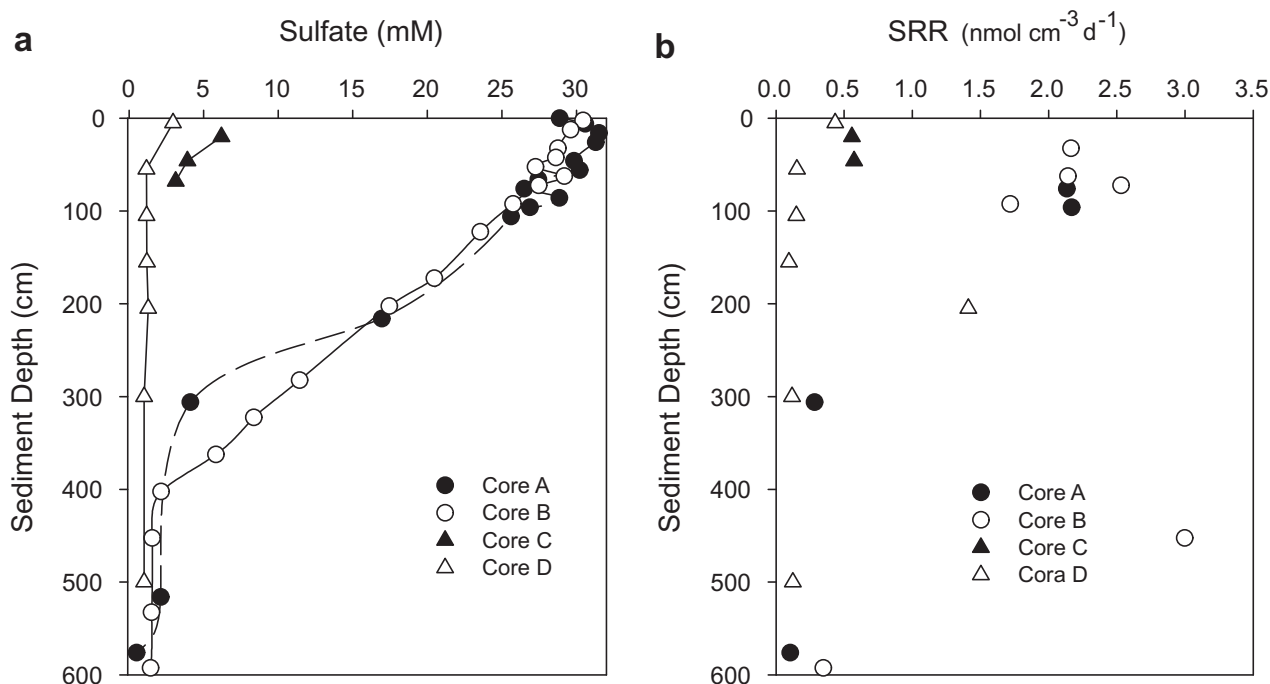

Fig. 9. Sulfate concentration (a) and sulfate reduction rates (b) in cores obtained during cruise PGC01-03.

\section{DISCUSSION}

\subsection{Evidence for the anaerobic oxidation of methane (AOM) at Bullseye vent}

Geochemical data (Fig. 4) indicate AOM is active along the entire Bullseye vent transect and that elevated methane fluxes are concentrated above the seismic blanking features associated with gas and gas hydrate (Fig. 2b). Evidence for $\mathrm{AOM}$ is provided by $\delta^{13} \mathrm{C}$-DIC values at the SMT that range from $-47.5 \%$ to $-43.3 \%$ (Fig. 4) and are substantially more ${ }^{13} \mathrm{C}$-depleted than the bulk sediment $\mathrm{OM}$ $(-24.5 \% \pm 0.5$, Fig. 6). The only known mechanism for generating the observed DIC values at the SMT is oxidation of ${ }^{13} \mathrm{C}$-depleted methane by AOM (Claypool and Kaplan, 1974; Suess and Whiticar, 1989; Malinverno and Pohlman, 2011). SMT depths from cores overlying the $0.1 \mathrm{~km}^{2}$ gas and gas hydrate-associated blanking features (Cores 2, 3, 5 and 6; bound by the dashed grey line in Fig. 2b) are shallower than those distal to the seep (Cores 1, 4 and 7, Fig. 2b), suggesting elevated methane fluxes near the seep. Core 7, located at the greatest distance from the seep, has a SMT of $580 \mathrm{cmbsf}$, similar to the regional SMT depth for this portion of the northern Cascadia margin (500 cmbsf at IODP Site U1327; Riedel et al., 2006a). Thus, the coring transect captured the spatial distribution of enhanced methane flux at Bullseye vent.

Among 19 piston cores from Bullseye vent for which sulfate and methane profile data are available (Fig. 2b; 11 from Riedel et al., 2006b; 1 from Briggs et al., 2011; and 7 from this study), only Core 5 from this study contained methane near the sediment-seawater interface. Thus, despite a large accumulation of gas and gas hydrate within meters of the seafloor (dashed grey line in Fig. 2), the spatial extent of methane emissions from the seep is limited. The evidence for active AOM, combined with a limited area for sedimentary methane efflux at a gas hydrate-bearing seep requires a substantial sedimentary methane sink. We now consider how the sedimentary origins and burial history of Bullseye vent have enhanced the current methane oxidizing capacity of this seep.

\subsection{Delineating sediment origins and deposition at Bullseye vent}

\subsubsection{Incorporation of methane carbon in sedimentary carbon pools}

Using stable $\left({ }^{13} \mathrm{C}\right)$ and radiocarbon $\left({ }^{14} \mathrm{C}\right)$ isotope ratios of sedimentary carbon pools to infer OM sources and deposition rates at methane seeps may be confounded by the incorporation of methane carbon released by AOM. Terrigenous and marine OM sources in continental margin sediments offshore of Vancouver Island are distinguished by $\delta^{13} \mathrm{C}$ values of $-22 \%$ to $-20 \%$ for marine OM and $-27 \%$ for terrigenous OM (Meyers, 1997; McKay et al., 2004; Kaneko et al., 2010). Sediment deposition rates are based on the extent of radioactive decay of ${ }^{14} \mathrm{C}$ since death and burial of planktonic foraminifera (e.g., McKay et al., 2004). However, ${ }^{13} \mathrm{C}$-depleted (Whiticar, 1999) and ${ }^{14} \mathrm{C}$-depleted (Pohlman et al., 2009) methane carbon assimilated into the host sediment may obscure the ${ }^{13} \mathrm{C}$-based origins and ${ }^{14} \mathrm{C}$-based ages of carbonate and sediment (e.g., Paull et al., 1989). To properly utilize ${ }^{13} \mathrm{C}$ and ${ }^{14} \mathrm{C}$ based isotope proxies for sedimentary source and depositional rate studies in methane seeps, the extent to which the AOM-derived carbon alters various sedimentary carbon pools must be determined.

With the exception of three samples from the SMT of Core 5 (Fig. 6), the ${ }^{13} \mathrm{C}$-content of the TOC $(-24.5 \% \pm 0.5)$ is constant and reflects a simple mixture of terrigenous OM $(-27 \%)$ and marine phytoplankton $(-21 \%$ ) (McKay et al., 2004; Kaneko et al., 2010). By contrast, the $\delta^{13} \mathrm{C}$ values of the bulk carbonate $(-27.0 \%$ to $+2.5 \%$ are, for the most part, substantially more ${ }^{13} \mathrm{C}$-depleted than the regional range $(-1$ to $+1 \%$ ) for biogenic carbonate (Ortiz et al., 1996) (Fig. 7). Thus, while the 
Table 3

Planktic foram mass balance radiocarbon $\left({ }^{14} \mathrm{C}\right)$ correction inputs and outputs.

\begin{tabular}{|c|c|c|c|c|c|c|c|}
\hline Core & $\begin{array}{l}\text { Depth } \\
(\mathrm{cmbsf})\end{array}$ & $\begin{array}{l}\text { Percent authigenic } \\
\text { carbonate }^{\mathrm{a}}\end{array}$ & $\begin{array}{l}\text { Measured } \\
\mathrm{D}^{14} \mathrm{C}^{\mathrm{b}}(\%)\end{array}$ & $\begin{array}{l}\text { Corrected } \\
\mathrm{D}^{14} \mathrm{C}^{\mathrm{c}}(\% \mathrm{oo})\end{array}$ & $\begin{array}{l}\text { Corrected }{ }^{14} \mathrm{C} \text { age }{ }^{\mathrm{d}} \\
(\mathrm{yr} \mathrm{BP})\end{array}$ & $\begin{array}{l}\Delta- \\
\mathrm{Age}^{\mathrm{e}}\end{array}$ & $\begin{array}{l}\text { Calendar age }^{\mathrm{f}} \\
(\mathrm{kyr} \mathrm{BP} \pm 1 \sigma)\end{array}$ \\
\hline PGC02-08-05 & $\begin{array}{r}70 \\
95 \\
130 \\
210\end{array}$ & $\begin{array}{l}7.2 \pm 1.0 \\
11.6 \pm 1.3 \\
8.4 \pm 1.1 \\
10.5 \pm 1.2\end{array}$ & $\begin{array}{l}-863 \pm 3 \\
-864 \pm 4 \\
-865 \pm 4 \\
-865 \pm 4\end{array}$ & $\begin{array}{l}-860 \pm 3 \\
-858 \pm 5 \\
-861 \pm 4 \\
-860 \pm 5\end{array}$ & $\begin{array}{l}15800 \pm 160 \\
15650 \pm 260 \\
15850 \pm 250 \\
15750 \pm 270\end{array}$ & $\begin{array}{l}150 \\
400 \\
300 \\
350\end{array}$ & $\begin{array}{l}17.78 \pm 0.66 \\
17.57 \pm 0.91 \\
17.90 \pm 0.71 \\
17.73 \pm 0.95\end{array}$ \\
\hline PGC02-08-06 & $\begin{array}{l}120 \\
200 \\
330 \\
370 \\
496\end{array}$ & $\begin{array}{l}9.2 \pm 1.1 \\
12.0 \pm 1.3 \\
4.4 \pm 0.9 \\
4.8 \pm 0.9 \\
4.0 \pm 0.8\end{array}$ & $\begin{array}{l}-842 \pm 5 \\
-852 \pm 7 \\
-846 \pm 2 \\
-855 \pm 3 \\
-863 \pm 2\end{array}$ & $\begin{array}{l}-836 \pm 5 \\
-844 \pm 7 \\
-845 \pm 3 \\
-853 \pm 3 \\
-863 \pm 3\end{array}$ & $\begin{array}{l}14550 \pm 250 \\
14950 \pm 380 \\
15000 \pm 140 \\
15400 \pm 170 \\
15950 \pm 150\end{array}$ & $\begin{array}{r}300 \\
350 \\
50 \\
100 \\
50\end{array}$ & $\begin{array}{l}15.94 \pm 0.75 \\
16.49 \pm 1.13 \\
16.54 \pm 0.51 \\
17.17 \pm 0.67 \\
18.13 \pm 0.57\end{array}$ \\
\hline PGC02-08-07 & 573 & $3.4 \pm 0.9$ & $-845 \pm 6$ & $-843 \pm 6$ & $14900 \pm 310$ & 100 & $16.46 \pm 0.90$ \\
\hline
\end{tabular}

${ }^{13} \mathrm{C}$-based evidence for methane incorporation to TOC is limited, it is strong for bulk carbonate.

Radiocarbon ages of the TOC and bulk carbonate are both older than the planktonic foraminifera (Fig. 8). For TOC, the age offset from the planktonic foraminifera is most likely related to contributions from pre-aged terrigenous OM (Raymond and Bauer, 2001; Ohkouchi et al., 2002). For bulk carbonate, the offset reflects incorporation of methane carbon with a reported $\Delta{ }^{14} \mathrm{C}$ value of $-985 \%$ (Pohlman et al., 2009); equivalent to a radiocarbon age of $\sim 34,000$ yrs. Planktonic foraminifera, the sediment component most frequently used to calculate sediment accumulation rates in marine sediments, possess the youngest radiocarbon ages among the paired samples (Fig. 8). However, $\delta^{13} \mathrm{C}$ values as low as $-5.2 \%$ for the planktonic foraminifera (Table 2) imply that precipitation of methane-derived authigenic carbonate (AC) might also have influenced the measured radiocarbon ages. This observation is consistent with previous studies where the primary biogenic signal of living and dead foraminiferal tests in hydrate-bearing cold seeps was altered by methane-derived AC (Torres et al., 2003; Hill et al., 2004).

\subsubsection{Mass balance-corrected sedimentation rates}

To obtain an accurate chronostratigraphy for Bullseye vent, isotopic alterations caused by precipitation of methane-derived AC on planktonic foraminifera tests are corrected through a series of isotope mass balances using a general 2-source isotope mixing model (Eq. (4)) as

$X_{\text {foram }}=\left(X_{\mathrm{DIC}} * f_{\mathrm{AC}}\right)+\left(X_{\text {biogenic }} *\left(1-f_{\mathrm{AC}}\right)\right)$,

where $X$ is the measured $\delta^{13} \mathrm{C}$ or $\mathrm{D}^{14} \mathrm{C}$ of the foraminifera $\left(X_{\text {foram }}\right)$, pore water DIC $\left(X_{\text {DIC }}\right)$ or pure biogenic calcite $\left(X_{\text {biogenic }}\right)$. Because AC forms when components of DIC generated during AOM (Eq. (1)) precipitate at the SMT
(Kulm et al., 1986; Paull et al., 1992; Aloisi et al., 2002), the isotopic signature of $\mathrm{AC}$ is represented by the measured isotopic signature of DIC $\left(X_{\mathrm{DIC}}\right)$ at the SMT. This approach assumes the isotopic composition of the measured DIC is similar to when the carbonate precipitated on the foraminiferal tests. The pure biogenic calcite component ( $X_{\text {biogenic }}$ ) is the calculated isotopic signature for unaltered planktonic foraminifera.

The fraction of $\mathrm{AC}\left(f_{\mathrm{AC}}\right)$ present in foraminifera is calculated by rearranging Eq. (4) and inserting appropriate $\delta^{13} \mathrm{C}$ values as:

$F_{\text {AC }}=\frac{\left(\delta^{13} \mathrm{C}_{\text {foram }}-\delta^{13} \mathrm{C}_{\text {biogenic }}\right)}{\left(\delta^{13} \mathrm{C}_{\text {DIC }}-\delta^{13} \mathrm{C}_{\text {biogenic }}\right)}$

where the $\delta^{13} \mathrm{C}$ for pure biogenic calcite $\left(\delta^{13} \mathrm{C}_{\text {biogenic }}\right)$ is $0.0 \pm$ $0.5 \%$ (Ortiz et al., 1996), $\delta^{13} \mathrm{C}$ for DIC $\left(\delta^{13} \mathrm{C}_{\text {DIC }}\right)$ is the pore water $\delta^{13} \mathrm{C}$-DIC value at the SMT for each core (Fig. 4), and $\delta^{13} \mathrm{C}$ values for planktonic foraminifera $\left(\delta^{13} \mathrm{C}_{\text {foram }}\right)$ are those directly measured or estimated (Table 2 ). Model results (Table 3) indicate that post-depositional accumulation of AC accounts for $\sim 3-12 \%$ of carbonate in planktonic foraminifera. These findings are similar to those from Hydrate Ridge where AC comprised of $3-20 \%$ of foraminiferal tests (Torres et al., 2003).

The biogenic $\mathrm{D}^{14} \mathrm{C}$ values $\left(\mathrm{D}^{14} \mathrm{C}_{\text {biogenic }}\right.$ ) for planktonic foraminifera are calculated by rearranging Eq. (5) and inserting appropriate $\mathrm{D}^{14} \mathrm{C}$ values (Eq. (6)) as

$\mathrm{D}^{14} \mathrm{C}_{\text {biogenic }}=\frac{\mathrm{D}^{14} \mathrm{C}_{\text {foram }}-\left(\mathrm{D}^{14} \mathrm{C}_{\mathrm{DIC}} * f_{\mathrm{AC}}\right)}{\left(1-f_{\mathrm{AC}}\right)}$

where $f_{A C}$ is the fractional contribution of AC (Table 3), $\mathrm{D}^{14} \mathrm{C}_{\mathrm{DIC}}$ is the $\mathrm{D}^{14} \mathrm{C}$ of pore water DIC nearest the SMT (Fig. 5; see Electronic Annex for actual values), and $\mathrm{D}^{14} \mathrm{C}_{\text {foram }}$ is the measured $\mathrm{D}^{14} \mathrm{C}$ of planktonic foraminifera 


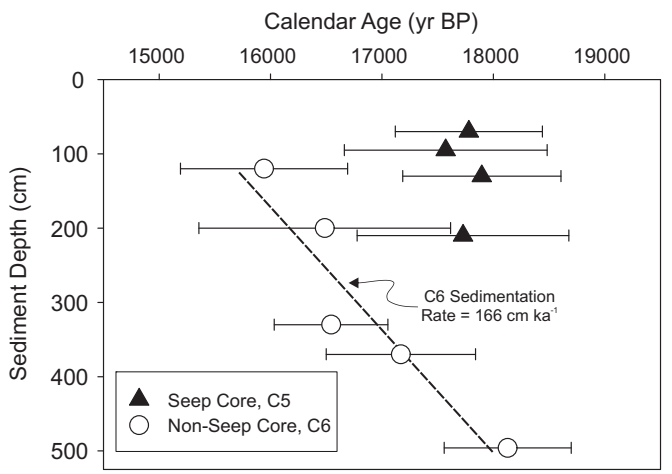

Fig. 10. Age-depth profiles $( \pm 1 \sigma)$ for the calendar age model based on mass-balance age corrections described in the text. The error bars represent the propagated error from all analytical, calibration and mass balance correction uncertainties.

from each sample (Table 3 ). The corrected $\mathrm{D}^{14} \mathrm{C}$ values are converted to ${ }^{14} \mathrm{C}$ ages (Stuiver and Polach, 1977) as:

${ }^{14} \mathrm{C}_{\text {Age }}=-8033 \times \ln \left(1+\frac{\mathrm{D}^{14} \mathrm{C}_{\text {biogenic }}}{1000}\right)$

The ${ }^{14} \mathrm{C}$ ages for the foraminifera corrected for AC (see Table 3) are 50-400 yrs younger than the uncorrected values (see Table 2). The $1 \sigma$ age error for these corrected values represents the combined propagated errors from the ${ }^{14} \mathrm{C}$ analysis, the $\delta^{13} \mathrm{C}$ calculation (where applied) and the ${ }^{13} \mathrm{C}$ and ${ }^{14} \mathrm{C}$-based mass balance corrections. In turn, radiocarbon ages were converted to calendar ages using the Marine04 calibration curve (Hughen et al., 2004) and the correction for reservoir effects $(0.8-1.6 \mathrm{ka})$ for this region (Kienast and McKay, 2001). Age-depth profiles using the corrected values (Fig. 10) display a trend of increasing age with depth for Core 6 not observed using the uncorrected ${ }^{14} \mathrm{C}$ ages of the planktonic foraminifera (Fig. 8). A sedimentation rate of $166 \mathrm{~cm} \mathrm{ka}^{-1}$ is interpolated from the corrected Core 6 profile (Fig. 10).

\subsubsection{Bullseye vent: a glacial-marine sediment methane seep}

The corrected planktonic foraminiferal ages from Cores 5 , 6 and 7 range from 14,550 to 15,950 radiocarbon $\left({ }^{14} \mathrm{C}\right)$ yrs BP, or 15,940 to 18,130 calendar yrs BP (Table 3 ). That time interval corresponds with the late glacial period of the last glacial maximum (LGM) (Cosma and Hendy, 2008). The maximum extent of glaciation on the continental slope offshore of Vancouver Island during the last glacial maximum occurred $\sim 19 \mathrm{ka} \mathrm{BP}$. Retreat of the ice sheet began $\sim 17$ ka BP (Blaise et al., 1990). From the peak of glaciation until approximately $14.6 \mathrm{ka} \mathrm{BP}$ - a period that entirely encompasses the age of material recovered in cores from Bullseye vent - large quantities of sediment comprised of glacially-derived lithogenic sediment and predominantly terrigenous OM (McKay et al., 2004; Cosma and Hendy, 2008) were deposited along the continental margin (Clague and James, 2002). Sedimentation rates reported for this continental slope during this time period are $160 \mathrm{~cm} \mathrm{ka}^{-1}$ (Blaise et al., 1990), $47 \mathrm{~cm} \mathrm{ka}^{-1}$ (McKay et al., 2004) and $\sim 110-480 \mathrm{~cm} \mathrm{ka}^{-1}$ (Cosma and Hendy, 2008) (see
Fig. 2a for the core locations). The average calculated sedimentation rate interpolated from the age-depth profile from Core $6\left(166 \mathrm{~cm} \mathrm{ka}^{-1}\right.$, Fig. 10) is within the range of these studies. Thus, the dated sediments, ranging in depth from 70 to $573 \mathrm{cmbf}$, were unequivocally deposited during the period of deglaciation following the LGM.

$\delta^{13} \mathrm{C}$-TOC data from our 74 samples represents a more extensive vertical range $(5-818 \mathrm{cmbsf})$ and resolution than the radiocarbon dataset, and provides an opportunity to further delineate the Bullseye vent sediment origins. Calculations using a 2-source isotope mass balance equation (Eq. (4)) with a marine end member value of $-21 \%$, a terrigenous end member value of $-27 \%$ and the measured value for each TOC sample, indicate that $63 \pm 9 \%$ of the TOC from all Bullseye vent profiles (Fig. 6) is terrigenous in origin. Consistent with this calculation, terrestrial OM contributions for sites located $14 \mathrm{~km}$ (McKay et al., 2004) and $37 \mathrm{~km}$ (Cosma and Hendy, 2008) from Bullseye vent were estimated to range from $50 \%$ to $70 \%$ for the same time interval. Similarly high levels of terrigenous contributions to the northern Cascadia margin are only documented for late-glacial and early-deglacial periods of the LGM, which strongly suggests the entire upper $8 \mathrm{~m}$ of sediment at Bullseye vent was deposited before $14.6 \mathrm{ka} \mathrm{BP}$, when rapid warming began during the Bølling (McKay et al., 2004) and terrigenous and lithogenic contributions decreased (McKay et al., 2004; Cosma and Hendy, 2008).

\subsection{Tectonic control of sedimentation at Bullseye vent}

Although glacial marine sediments accumulated rapidly over large areas offshore of Vancouver Island during the last deglacial, the absence of Holocene-aged sediment at Bullseye vent is distinct from nearby non-seep slope sites investigated by McKay et al. (2004) and Cosma and Hendy (2008), where 3.5 and $5.0 \mathrm{~m}$, respectively, of post-glacial sediment with $\mathrm{OM}$ of predominant marine origin is present (see Fig. 2a for core locations). The depositional history at Bullseye vent is related to the tectonic framework of the margin, as described below.

Multichannel seismic (MCS) data show that Bullseye vent overlies minibasin deposits that have been uplifted by $\sim 225 \mathrm{~m}$ relative to a landward slope basin (Fig. 3b). Two discontinuous and vertically offset turbidite sequences visible in seismic profiles of the mini-basin and the slope-basin (dashed lines in Fig. 3b) may have been a continuous stratigraphic unit prior to uplift. The prominent $\sim 225 \mathrm{~m}$ eastward-facing fault scarp (Fig. 3b) that formed during uplift now isolates Bullseye vent from down-slope sedimentation by turbidity currents and exposes it to bottom water currents that have starved the platform of hemipelagic sedimentation since at least the Early Holocene (see Section 5.2.3). Thick deposits of glacial-marine sediments on this turbidite-isolated ridge suggest the ice sheet that melted in this area during the Late Pleistocene resulted in the deposition of sediments on this platform. Indeed, the Cordilleran Ice Sheet advanced onto the continental shelf to within $45 \mathrm{~km}$ of Bullseye vent $16.7 \mathrm{ka}$ BP (Blaise et al., 1990), which is within the $2000 \mathrm{yr}$ period when more than $5 \mathrm{~m}$ of sediment was deposited at Bullseye vent (Fig. 10). 
Exposure of the uplifted ridge to bottom water currents may also have caused the seafloor to erode. The ages of planktonic foraminifera from within the Bullseye vent depression (Core 5) are older than foraminifera from shallower sediment depths outside the depression (Core 6) (Fig. 10). Older sediment within the seep depression is consistent with sediment loss resulting from gas and fluid seepage (Hovland and Judd, 1988), erosion caused by ocean currents (Hammer et al., 2009) or some combination of both. Furthermore, because authigenic carbonate forms in the subsurface as a by-product of AOM at cold seeps (Kulm et al., 1986; Paull et al., 1992; Aloisi et al., 2002), methane-derived authigenic carbonate outcropping the seafloor is additional evidence for seafloor erosion (Paull and Ussler, 2008).

\subsection{Evidence for coupled AOM and sulfate reduction}

We hypothesize that the organically lean, aged and weathered surface sediment at Bullseye vent is recalcitrant and therefore unlikely to support significant organoclastic $\mathrm{SR}$. If so, AOM and sulfate reduction coupled by the $1: 1$ stoichiometry in Eq. (1) is the expected dominant sink for sulfate. To test our hypothesis, we compare sulfate reduction rates from Bullseye vent to those from other seeps to establish general relationships between SR rates and the availability of $\mathrm{OM}$ at seeps. We then utilize a radiocarbon-based DIC isotope mass balance model to identify the $\mathrm{OM}$ sources and processes contributing DIC to pore fluids at Bullseye vent.

\subsubsection{Sulfate reduction rates}

The AOM component of SR rates from ex situ incubations is greatly underestimated because methane (substrate for AOM) escapes during sample recovery (Bowles et al., 2011a). Sample depressurization does not, however, reduce substrate availability for organoclastic SR. Thus, SR rate differences among sites with similar methane availability may be attributed to the OM-based SR rate component with OM-poor seeps being expected to have lower total SR rates because methane-based SR is inhibited by substrate loss and OM-based SR is limited by substrate availability. Accordingly, volumetric SR rates from the Bullseye vent depression (0.1-3.0 nmol cm $\mathrm{cm}^{-3} \mathrm{~d}^{-1}$; Fig. 9b) are equal to or less than the lowest SR rates from studies of other active seeps in the GoM (Joye et al., 2004; Orcutt et al., 2010; Bowles et al., 2011b), Southern Hydrate Ridge (Treude et al., 2003), Gulf of Cadiz (Niemann et al., 2006a) and the Haakon Mosby mud volcano (Niemann et al., 2006b). Indeed, the maximum SR rates from seeps with abundant non-methane OM sources in the GoM and on Hydrate Ridge are often three or more orders of magnitude greater than the Bullseye vent SR rates. By contrast, the maximum SR rates from Bullseye vent are similar to maximum rates from the OM-poor Woodland Basin near Papua New Guinea in the Pacific Ocean (1.3-4.8 $\mathrm{nmol} \mathrm{cm} \mathrm{c}^{-3} \mathrm{~d}^{-1}$; Wellsbury et al., 2002) and are comparable to Gulf of Cadiz mud volcanoes $\left(15-25 \mathrm{nmol} \mathrm{cm}^{-3} \mathrm{~d}^{-1}\right)$ where TOC content is $<0.35 \mathrm{wt} . \%$ TOC (Niemann et al., 2006a). Although some OM-rich continental margin settings have similar SR rates as Bullseye

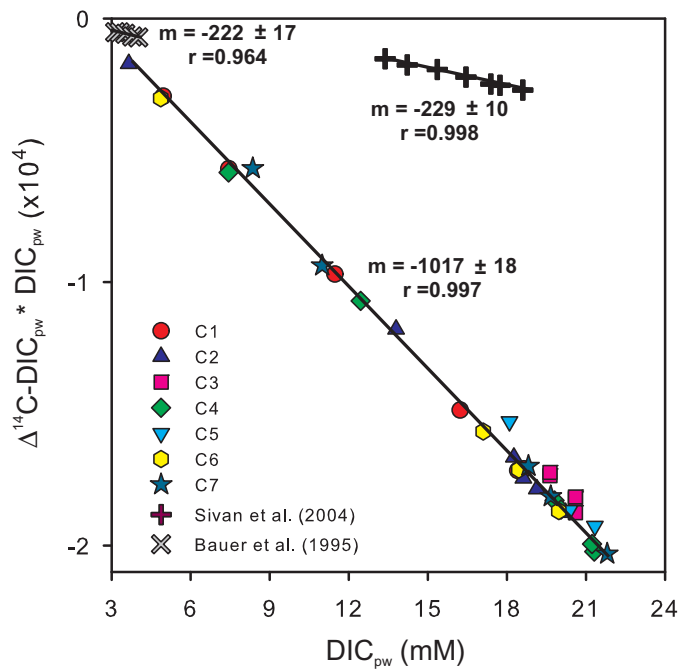

Fig. 11. Radiocarbon isotope mass balance model for determining the ${ }^{14} \mathrm{C}$ content of dissolved inorganic carbon (DIC) contributed by sediment diagenesis $\left(\Delta^{14} \mathrm{C}_{\text {sed }}\right.$ in Eq. (8)). Slopes $(m)$ determined by geometric mean regression analysis are $\Delta^{14} \mathrm{C}_{\text {sed. }}$. The colored symbols are from cores analyzed in this study. Additional data are from southeast Mediterranean Sea continental shelf sediments (†, Sivan et al., 2004) and Santa Monica Basin (SMB) sediments in the eastern North Pacific Ocean ( $\mathbb{X}$, Bauer et al., 1995). DIC additions from Bullseye vent are fossil (i.e., $\Delta^{14} \mathrm{C}=-1000 \%$ ) in origin, which precludes non-fossil TOC (see Fig. 8) from within the sulfate reduction zone as a source of DIC. By contrast, the relatively ${ }^{14} \mathrm{C}$-enriched DIC additions from the SE Mediterranean Sea and the SMB are derived from a non-fossil, shallow carbon source.

vent (e.g., Treude et al., 2005; Niewöhner et al., 1998), rates of SR at OM-poor seeps are, in general, low relative to OMrich seeps. We suggest this observation is related to limited sedimentary OM bioavailability at OM-poor seeps.

\subsubsection{DIC-based radiocarbon $\left({ }^{14} C\right)$ mass balance model}

To assess the relative contributions of $\mathrm{OM}$ and methane as substrates for SR at Bullseye vent, we employ an isotope mass balance model to calculate the ${ }^{14} \mathrm{C}$-content of DIC added to pore fluids since burial. From that, we determine the contribution from OM decomposition within the SZ. This approach takes advantage of the differing ${ }^{14} \mathrm{C}$-content of sediment TOC $\left(\Delta^{14} \mathrm{C}=-923 \%\right.$ to $-825 \%$, Fig. 8) and gas hydrate-bound methane $\left(\Delta^{14} \mathrm{C}=-985 \%\right.$, Pohlman et al., 2009) to identify DIC sources. Isotopic mass balance models have been used to determine the radiocarbon composition of particulate organic carbon added to riverine and marine sediments (Blair et al., 2003), dissolved organic carbon (DOC) added to nearshore and open ocean systems (Mortazavi and Chanton, 2004) and seep-derived DOC expelled from gas hydrate-bearing seeps (Pohlman et al., 2011). The ${ }^{14} \mathrm{C}$-content of the pore water DIC is an integrated signal from buried seawater DIC and DIC produced during early sediment diagenesis (including AOM, organoclastic SR and net methanogenesis), an approach that is complementary to rate measurements targeting specific processes. The $\Delta^{14} \mathrm{C}$ value of pore water DIC $\left(\Delta^{14} \mathrm{C}_{\mathrm{pw}}\right)$ is de- 
scribed by a two-source end member model, expressed in terms of the DIC concentration in each sample,

$C_{\mathrm{pw}} \cdot \Delta^{14} \mathrm{C}_{\mathrm{pw}}=C_{\mathrm{sw}} \cdot \Delta^{14} \mathrm{C}_{\mathrm{sw}}+C_{\mathrm{sed}} \cdot \Delta^{14} \mathrm{C}_{\mathrm{sed}}$

$C_{\mathrm{pw}}=C_{\mathrm{sw}}+C_{\mathrm{sed}}$

where $C_{p w}$ is the total DIC concentration in each pore water sample, and $C_{s w}$ and $C_{s e d}$ are the DIC concentrations in each sample derived from the buried seawater component and the DIC contributed by sediment diagenesis, respectively. Similarly, $\Delta^{14} C_{p w}$ is the measured $\Delta^{14} \mathrm{C}$ value of the pore water DIC derived from seawater DIC $\left(\Delta^{14} C_{s w}\right)$ and DIC contributed by sediment diagenesis $\left(\Delta^{14} C_{\text {sed }}\right)$. Using Eq. (9) to replace $C_{\text {sed }}$ in Eq. (8) produces a linear equation where the slope, $m$, (Fig. 11) is equivalent to the $\Delta^{14} \mathrm{C}$ of the diagenetic DIC, $\Delta^{14} C_{\text {sed }}$. See the Electronic Annex for the measured $C_{p w}$ and $\Delta{ }^{14} C_{p w}$ values used in the model.

The model estimate for the $\Delta^{14} \mathrm{C}$ of the diagenetic DIC component $\left(\Delta^{14} C_{\text {sed }}\right)$ is $-1017 \pm 18 \%$ (Fig. 11), which is consistent with a DIC contribution from a strictly fossil carbon (i.e., $\Delta^{14} \mathrm{C}=-1000 \%$ ) source. Potential fossil or near-fossil DIC sources include methane $(-985 \%$, Pohlman et al., 2009) oxidized by AOM, as well as remineralization of deeply-buried fossil OM and DOC (Egeberg and Barth, 1998; Heuer et al., 2009). Because TOC in the SZ is nonfossil ( $-949 \%$ to $-470 \%$, Fig. 8 ), a significant contribution from TOC oxidized by SR is not possible. The model includes 36 DIC samples from all seven cores (Fig. 5; Table 4) along the transect, so this conclusion is independent of sediment depth or methane flux.

To test the robustness of the isotope mass balance model, we performed the same analysis using $\Delta^{14} \mathrm{C}$-DIC data from pore waters of shelf sediments in the southeastern Mediterranean Sea (Sivan et al., 2004) and the Santa Monica Basin in the California continental borderland (Bauer et al., 1995). The estimated $\Delta^{14} \mathrm{C}$ of diagenetic DIC added was $-229 \pm 18 \%$ and $-222 \pm 30 \%$, respectively, for the two studies (Fig. 11). In both cases, the inputs are consistent with and supported by additional evidence for at least a partial contribution from non-fossil OM decomposition by SR. Evidence that respiration of non-fossil OM added DIC into pore water at the non-seep sites investigated by Si- van et al. (2004) and Bauer et al. (1995), where AOM was not identified as an active process, bolsters the validity of the model results from this study and supports the conclusion that decomposition of sediment TOC by SR does not contribute significant quantities of DIC to pore waters at Bullseye vent.

\subsection{Sediment organic matter bioavailability as a structuring factor for methane biogeochemistry and emissions}

The geologic and geophysical setting of a seep is the primary structuring factor controlling the quantity of methane transported to the seafloor (e.g., Trehu et al., 2004). The fraction of that methane susceptible to AOM is determined by the quantity of sulfate penetrating the seafloor via molecular diffusion and fluid pumping by seep biota (Sahling et al., 2002; Torres et al., 2002; Niemann et al., 2006b), alternate electron acceptor availability (Beal et al., 2009), reoxidation of sulfides (Arvidson et al., 2004; Riedinger et al., 2010) and competition for sulfate by microbes that degrade oil and hydrocarbons (Joye et al., 2004; Orcutt et al., 2010). Our results suggest that sedimentary OM bioavailability is an additional factor regulating sulfate availability for AOM.

To evaluate if sedimentary OM-content is also related to AOM efficiency, we compared methane fluxes from the SMT to the sediment water interface (SWI) for Bullseye vent and a GoM methane seep with 3-times greater OMcontent (Lapham et al., 2008). Both cores were located in diffusion-dominated regions of the seep. Even though deeper SMTs at the GoM seep ( $593 \pm 261 \mathrm{cmbsf})$ have smaller incoming diffusive methane fluxes than the shallower Bullseye vent SMTs $(397 \pm 124 \mathrm{cmbsf})$, the GoM SMT to SWI methane flux $\left(0.53 \pm 0.22 \mu \mathrm{mol} \mathrm{m}{ }^{-2} \mathrm{~d}^{-1}\right)$ was, on average, 27 times greater than the Bullseye SMT to SWI flux $\left(0.02 \pm 0.02 \mu \mathrm{mol} \mathrm{m}{ }^{-2} \mathrm{~d}^{-1}\right)$ (Table 4). Thus, a greater fraction of methane fluxing into the OM-poor SMTs is consumed, suggesting a higher methane oxidation efficiency in OM-poor sediments within diffusive flux regimes.

Using the bathymetry and flux regime of Bullseye vent as a model, we define 3 regions where the effect of sedimentary OM-content on methane flux differs (Fig. 12). In Re-

Table 4

Methane fluxes from the sulfate methane transition (SMT) to the sediment water interface (SWI).

\begin{tabular}{|c|c|c|c|c|c|}
\hline Site & Core & SMT depth & $\begin{array}{l}\mathrm{CH}_{4} \text { gradient } \\
\left(\mu \mathrm{M} \mathrm{cm}^{-1}\right)\end{array}$ & $r^{2}$ & $\begin{array}{l}\text { Diffusive } \mathrm{CH}_{4} \text { flux to SWI } \\
\left(\mu \mathrm{mol} \mathrm{m} \mathrm{m}^{-2} \mathrm{~d}^{-1}\right)\end{array}$ \\
\hline \multirow[t]{4}{*}{ Bullseye vent } & $\mathrm{C} 1$ & 473 & 0.003 & 0.8 & 0.008 \\
\hline & $\mathrm{C} 4$ & 381 & 0.004 & 0.44 & 0.010 \\
\hline & C6 & 245 & $0.0102^{*}$ & 0.93 & 0.028 \\
\hline & $\mathrm{C} 7$ & 563 & $0.0022^{*}$ & 0.7 & 0.006 \\
\hline \multirow[t]{4}{*}{ Gulf of Mexico (MC118) } & 2 & 580 & 0.077 & 0.97 & 0.230 \\
\hline & 8 & 414 & 0.167 & 0.97 & 0.500 \\
\hline & 29 & 414 & 0.096 & 0.94 & 0.715 \\
\hline & 30 & 967 & 0.092 & 0.78 & 0.680 \\
\hline
\end{tabular}

\footnotetext{
* Surface value not included.

\$ Lapham et al. (2008).
} 


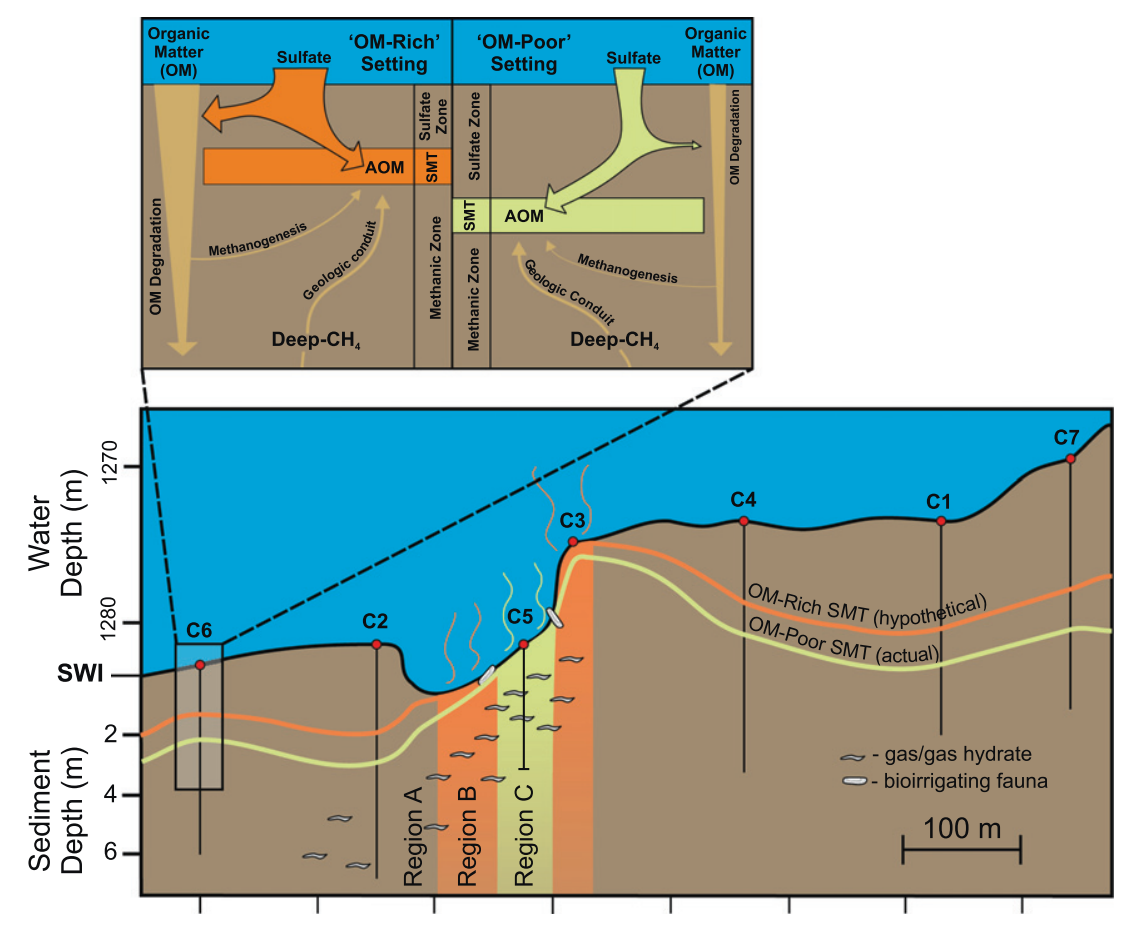

Fig. 12. Organic matter (OM) structuring of the sulfate-methane transition (SMT) in methane seeps. The figure is scaled to the dimensions, methane flux regime and coring locations of the PGC0208 transect across Bullseye vent, an OM-poor gas hydrate-bearing seep (Fig 2). The green line is the actual SMT depth determined from coring. The orange line is a hypothetical SMT for higher OM-content sediments and equivalent methane and sulfate flux potentials. Region A: (brown) the SMT is shallower for the OM-rich system; however, in both cases the SMT remains below the sediment-water interface (SWI). All methane is consumed by AOM and no methane is released. The inset above the main figure illustrates how OM-rich and OM-poor sediment systems respond to similar methane flux regimes and sulfate flux potentials. Region B: (orange) for the OM-rich condition only, the methane flux exceeds sulfate availability for AOM and methane discharges from the seafloor. Region C: (green) for both OM-content conditions, the methane flux exceeds sulfate availability for AOM and methane is released.

gion A, a steeper pore water sulfate gradient creates a shallower SMT in the OM-rich setting, thereby providing sufficient sulfate to satisfy AOM and organoclastic SR. All methane is quantitatively consumed in both the OM-poor and OM-rich scenarios. In Region B, there is sufficient sulfate flux to balance AOM and SR in the OM-poor system, but not the OM-rich system. The SMT is absent in the OMrich system and methane fluxes from the sediments to the overlying water column. In Region $\mathrm{C}$, the methane flux overwhelms AOM and SR regardless of sedimentary OMcontent. OM-content has the greatest influence on AOM capacity and methane emissions within Region B. The location and magnitude of methane emissions from Region B for a seep will depend on the net methane flux and the combination of factors that determine electron acceptor availability, including OM-content. Additional field investigations, laboratory studies and analytical models are necessary to quantify the role of OM-reactivity as a structuring factor for regulating methane emissions from seeps.

\subsection{Implications for ocean methane emissions}

Although oceanic methane emissions presently account for only $2 \%$ of the global atmospheric methane budget (Reeburgh, 2007), over millennial time scales ocean warm- ing has the potential to overwhelm AOM and release vast quantities of methane presently stored as gas hydrate to the ocean and atmosphere (Dickens et al., 1995). Previous methane releases associated with gas hydrate dissociation and dramatic ocean chemistry changes (Zachos et al., 2005) are recorded in the geologic record and coincide with warming events (Hinrichs et al., 2003; Kennett et al., 2003). With respect to contemporary climate change, gas hydrate within high-latitude continental margins is most vulnerable to dissociation (Maslin et al., 2010). Although it is not anticipated that methane liberated from gas hydrate will affect climate over the next several hundred years (Ruppel, 2011), models of warming along Arctic continental margins predict that hydrate destabilization and subsequent oxidation in the ocean will lead to ocean acidification and hypoxia, if present warming trends continue (Biastoch et al., 2011; Elliott et al., 2011). However, since AOM does not cause acidification or hypoxia, if AOM consumes more methane than recent studies assume (Biastoch et al., 2011; Elliott et al., 2011), the environmental impact of destabilized gas hydrate and gas released from sedimentary basins will be less than predicted.

High latitude margins frequently contain $2-3 \mathrm{~km}$ thick accumulations of Late Cenozoic glacigenic material that extend to the continental slope and rise (Dowdeswell, 1987; Elverhoi et al., 1995). In fact, the rate of sediment delivery 
by ice sheets exceeded that of the Amazon and Mississippi River systems by at least an order of magnitude during the late Cenozoic (Dowdeswell et al., 2010). Thus, OM-poor glacial-marine deposits most likely overlay at least some gas hydrate-bearing sediments within high-latitude continental margins. Our findings that methane seeps dominated by glacially-derived sediments may be more efficient AOM bioreactors than their OM-rich counterparts suggests that models and budgets quantifying the contribution, fate and impact of methane from seeps should consider seep sediment origins and OM reactivity.

\section{ACKNOWLEDGEMENTS}

We express gratitude to the captain and the crew of the $C C G V$ John P. Tully and Bob MacDonald for shipboard and logistical support. Clark Mitchell, Rebecca Plummer, David Knies and Brett Renfro provided valuable analytical support. Partial support for this research was provided by Interagency Agreements DE-FE0002911 and DE-NT0006147 between the US Geological Survey Gas Hydrates Project and the US Department of Energy's Methane Hydrates Research and Development Program. We thank Bill Waite and Marcos Yoshinaga for constructive comments and insight during the preparation of the manuscript and anonymous reviewers for critical comments that improved the manuscript. Any use of trade names is only for descriptive purposes and does not imply endorsement by the US Government.

\section{APPENDIX A. SUPPLEMENTARY DATA}

Supplementary data associated with this article can be found, in the online version, at http://dx.doi.org/10.1016/ j.gca.2013.01.022.

\section{REFERENCES}

Akiba F., Inoue Y., Saito-Kato M. and Pohlman J.W. (2009) Data report: diatom and foraminiferal assemblages in Pleistocene turbidite sediments from the Cascadia margin (IODP Expedition 311), northeast Pacific. In Proc. IODP, 311 (eds. M. Riedel, T. S. Collett, M. J. Malone and E. Scientists). Integrated Ocean Drilling Program Management International, Inc., Washington, DC.

Albert D. B., Taylor C. and Martens C. S. (1995) Sulfate reduction rates and low-molecular-weight fatty-acid concentrations in the water column and surficial sediments of the Black Sea. DeepSea Res. Part I 42, 1239-1260.

Aloisi G., Bouloubassi I., Heijs S. K., Pancost R. D., Pierre C., Damste J. S. S., Gottschal J. C., Forney L. J. and Rouchy J. M. (2002) $\mathrm{CH}_{4^{-}}$ consuming microorganisms and the formation of carbonate crusts at cold seeps. Earth Planet. Sci. Lett. 203, 195-203.

Alperin M. J. and Hoehler T. M. (2009) Anaerobic methane oxidation by archaea/sulfate-reducing bacteria aggregates: 2 . Isotopic constraints. Am. J. Sci. 309, 958-984.

Alperin M. J., Reeburgh W. S. and Whiticar M. J. (1988) Carbon and hydrogen isotope fractionation resulting from anaerobic methane oxidation. Global Biogeochem. Cycles 2, 279288.

Arvidson R. S., Morse J. W. and Joye S. B. (2004) The sulfur biogeochemistry of chemosynthetic cold seep communities, Gulf of Mexico, USA. Mar. Chem. 87, 97-119.
Bauer J. E., Reimers C. E., Druffel E. R. M. and Williams P. M. (1995) Isotopic constraints on carbon exchange between deep ocean sediments and sea water. Nature 373, 686-689.

Beal E. J., House C. H. and Orphan V. J. (2009) Manganese- and iron-dependent marine methane oxidation. Science 325, 184 187.

Berner R. A. (1980) Early Diagenesis: A Theoretical Approach. Princeton University Press, Princeton, NJ, 241 pp.

Biastoch A., Treude T., Rupke L. H., Riebesell U., Roth C., Burwicz E. B., Park W., Latif M., Boning C. W., Madec G. and Wallmann K. (2011) Rising Arctic Ocean temperatures cause gas hydrate destabilization and ocean acidification. Geophys. Res. Lett. 38.

Blair N. E., Leithold E. L., Ford S. T., Peeler K. A., Holmes J. C. and Perkey D. W. (2003) The persistence of memory: the fate of ancient sedimentary organic carbon in a modern sedimentary system. Geochim. Cosmochim. Acta 67, 63-73.

Blaise B., Clague J. J. and Mathewes R. W. (1990) Time of maximum late Wisconsin glaciation, West-Coast of Canada. Quaternary Res. 34, 282-295.

Boehme S. E., Blair N. E., Chanton J. P. and Martens C. S. (1996) A mass balance of ${ }^{13} \mathrm{C}$ and ${ }^{12} \mathrm{C}$ in an organic-rich methaneproducing marine sediment. Geochim. Cosmochim. Acta 60, 3835-3848.

Boetius A., Ravenschlag K., Schubert C. J., Rickert D., Widdel F., Gieseke A., Amann R., Jorgensen B. B., Witte U. and Pfannkuche O. (2000) A marine microbial consortium apparently mediating anaerobic oxidation of methane. Nature $\mathbf{4 0 7}$, 623-626.

Bornhold B. D. and Barrie J. V. (1991) Surficial sediments on the western Canadian continental-shelf. Cont. Shelf Res. 11, 685699.

Bowles M. W., Samarkiin V. A. and Joye S. A. (2011a) Improved measurements of microbial activity in deep-sea sediments at in situ pressure and methane concentration. Limnol. Oceanogr. Methods 9, 499-506.

Bowles M. W., Samarkin V. A., Bowles K. M. and Joye S. B. (2011b) Weak coupling between sulfate reduction and the anaerobic oxidation of methane in methane-rich seafloor sediments during ex situ incubation. Geochim. Cosmochim. Acta 75, 500-519.

Briggs B. R., Pohlman J. W., Torres M., Riedel M., Brodie E. L. and Colwell F. S. (2011) Macroscopic biofilms in fracturedominated sediment that anaerobically oxidize methane. Appl. Environ. Microbiol. 77, 6780-6787.

Carson B., Westbrook G.K., Musgrave R.J. and Suess E. (1995) Proceedings of the Ocean Drilling Program Scientific Results, 146 (Pt. 1). Ocean Drilling Program, College Station, TX.

Clague J. J. and James T. S. (2002) History and isostatic effects of the last ice sheet in southern British Columbia. Quatern. Sci. Rev. 21, 71-87.

Claypool G. E. and Kaplan I. R. (1974) The origin and distribution of methane in marine sediments. In Natural Gases in Marine Sediments (ed. I. R. Kaplan). Plenum Press, New York, pp. 99 139.

Cosma T. and Hendy I. L. (2008) Pleistocene glacimarine sedimentation on the continental slope off Vancouver Island, British Columbia. Mar. Geol. 255, 45-54.

Dickens G. R., Oneil J. R., Rea D. K. and Owen R. M. (1995) Dissociation of oceanic methane hydrate as a cause of the carbon-isotope excursion at the end of the Paleocene. Paleoceanography 10, 965-971.

Dowdeswell J. A. (1987) Processes of glacimarine sedimentation. Prog. Phys. Geogr. 11, 52-90. 
Dowdeswell J. A., Ottesen D. and Rise L. (2010) Rates of sediment delivery from the Fennoscandian Ice Sheet through an ice age. Geology 38, 3-6.

Egeberg P. K. and Barth T. (1998) Contribution of dissolved organic species to the carbon and energy budgets of hydrate bearing deep sea sediments (Ocean Drilling Program Site 997 Blake Ridge). Chem. Geol. 149, 25-35.

Elliott S., Maltrud M., Reagan M., Moridis G. and CameronSmith P. (2011) Marine methane cycle simulations for the period of early global warming. J. Geophys Res. Biogeo., 116.

Elverhoi A., Svendsen J. I., Solheim A., Andersen E. S., Milliman J., Mangerud J. and Hooke R. L. (1995) Late quaternary sediment yield from the high Arctic Svalbard area. J. Geol. 103, 1-17.

Grabowski K. S., Knies D. L., DeTurck T. M., Treacy D. J., Pohlman J. W., Coffin R. B. and Hubler G. K. (2000) A report on the Naval Research Laboratory AMS facility. Nucl. Instrum. Methods Phys. Res. Sect.B-Beam Interact Mater. Atoms. 172, 34-39.

Hammer O., Webb K. E. and Depreiter D. (2009) Numerical simulation of upwelling currents in pockmarks, and data from the Inner Oslofjord, Norway. Geo. Mar. Lett. 29, 269-275.

Heuer V. B., Pohlman J. W., Torres M. E., Elvert M. and Hinrichs K. U. (2009) The stable carbon isotope biogeochemistry of acetate and other dissolved carbon species in deep subseafloor sediments at the northern Cascadia Margin. Geochim. Cosmochim. Acta 73, 3323-3336.

Hill T. M., Kennett J. P. and Valentine D. L. (2004) Isotopic evidence for the incorporation of methane-derived carbon into foraminifera from modern methane seeps, Hydrate Ridge, Northeast Pacific. Geochim. Cosmochim. Acta 68, 4619-4627.

Hinrichs K. U. and Boetius A. (2002) The anaerobic oxidation of methane: new insights in microbial ecology and biogeochemistry. In Ocean Margin Systems (eds. G. Wefer, D. Billett, B. B. Jorgensen, M. Schluter and T. van Weering). Springer, Heidelberg, pp. 457-477.

Hinrichs K. U., Hayes J. M., Sylva S. P., Brewer P. G. and Delong E. F. (1999) Methane-consuming archaebacteria in marine sediments. Nature 398, 802-805.

Hinrichs K. U., Hmelo L. R. and Sylva S. P. (2003) Molecular fossil record of elevated methane levels in late pleistocene coastal waters. Science 299, 1214-1217.

Hoehler T. M., Alperin M. J., Albert D. B. and Martens C. S. (1994) Field and laboratory studies of methane oxidation in an anoxic marine sediment - evidence for a methanogen-sulfate reducer consortium. Global Biogeochem. Cycles 8, 451-463.

Hovland M. and Judd A. G. (1988) Seabed Pockmarks and Seepages. Graham and Trotman, London.

Hughen K. A., Baillie M. G. L., Bard E., Beck J. W., Bertrand C. J. H., Blackwell P. G., Buck C. E., Burr G. S., Cutler K. B., Damon P. E., Edwards R. L., Fairbanks R. G., Friedrich M., Guilderson T. P., Kromer B., McCormac G., Manning S., Ramsey C. B., Reimer P. J., Reimer R. W., Remmele S., Southon J. R., Stuiver M., Talamo S., Taylor F. W., Van der Plicht J. and Weyhenmeyer C. E. (2004) Marine04 marine radiocarbon age calibration, 0$26 \mathrm{cal} \mathrm{kyr} \mathrm{BP.} \mathrm{Radiocarbon} \mathrm{46,} \mathrm{1059-1086.}$

Jørgensen B. B. (1978) Comparison of methods for the quantification of bacterial sulfate reduction in coastal marine-sediments: 1. Measurement with radiotracer techniques. Geomicrobiol. J. 1, 11-27.

Joye S. B., Boetius A., Orcutt B. N., Montoya J. P., Schulz H. N., Erickson M. J. and Lugo S. K. (2004) The anaerobic oxidation of methane and sulfate reduction in sediments from Gulf of Mexico cold seeps. Chem. Geol. 205, 219-238.

Judd A. G. (2004) Natural seabed gas seeps as sources of atmospheric methane. Environ. Geol. 46, 988-996.
Kaneko M., Shingai H., Pohlman J. W. and Naraoka H. (2010) Chemical and isotopic signature of bulk organic matter and hydrocarbon biomarkers within mid-slope accretionary sediments of the northern Cascadia margin gas hydrate system. Mar. Geol. 275, 166-177.

Kennett J.P., Cannariato K.G., Hendy I.L. and Behl R.J. (2003) Methane hydrates in quaternary climate change. American Geophysical Union, Washington, DC.

Kennett J. P. and Ingram B. L. (1995) A 20,000 year record of ocean circulation and climate-change from the Santa-Barbara basin. Nature 377, 510-514.

Kienast S. S. and McKay J. L. (2001) Sea surface temperatures in the subarctic Northeast Pacific reflect millennial-scale climate oscillations during the last 16 kyrs. Geophys. Res. Lett. 28, 1563-1566.

Kulm L. D., Suess E., Moore J. C., Carson B., Lewis B. T., Ritger S. D., Kadko D. C., Thornburg T. M., Embley R. W., Rugh W. D., Massoth G. J., Langseth M. G., Cochrane G. R. and Scamman R. L. (1986) Oregon subduction zone - Venting, fauna, and carbonates. Science 231, 561-566.

Kvenvolden K. A. and Rogers B. W. (2005) Gaia's breath - global methane exhalations. Mar. Petrol Geol. 22, 579-590.

Lapham L. L., Chanton J. P., Martens C. S., Sleeper K., and Woolsey J. R. (2008) Microbial activity in surficial sediments overlying acoustic wipeout zones at a Guld of Mexico cold seep. Geochem. Geophys. Geosys. 9. http://dx.doi.org/10.1029/2008G C001944.

Malinverno A. and Pohlman J. W. (2011) Modeling sulfate reduction in methane hydrate-bearing continental margin sediments: does a sulfate-methane transition require anaerobic oxidation of methane? Geochem. Geophys. Geosyst. 12.

Maslin M., Owen M., Betts R., Day S., Dunkley Jones T. and Ridgwell A. (2010) Gas hydrates: past and future geohazard? Philos. Trans. R. Soc. A 368, 2369-2393.

McKay J. L., Pedersen T. F. and Kienast S. S. (2004) Organic carbon accumulation over the last $16 \mathrm{kyr}$ off Vancouver Island, Canada: evidence for increased marine productivity during the deglacial. Quatern. Sci. Rev. 23, 261-281.

Meyers P. A. (1997) Organic geochemical proxies of paleoceanographic, paleolimnologic, and paleoclimatic processes. Org. Geochem. 27, 213-250.

Mortazavi B. and Chanton J. P. (2004) Use of Keeling plots to determine sources of dissolved organic carbon in nearshore and open ocean systems. Limnol. Oceanogr. 49, 102-108.

Niemann H., Duarte J., Hensen C., Omoregie E., Magalhaes V. H., Elvert M., Pinheiro L. M., Kopf A. and Boetius A. (2006a) Microbial methane turnover at mud volcanoes of the Gulf of Cadiz. Geochim. Cosmochim. Acta 70, 5336-5355.

Niemann H., Losekann T., de Beer D., Elvert M., Nadalig T., Knittel K., Amann R., Sauter E. J., Schluter M., Klages M., Foucher J. P. and Boetius A. (2006b) Novel microbial communities of the Haakon Mosby mud volcano and their role as a methane sink. Nature 443, 854-858.

Niewöhner C., Hensen C., Kasten S., Zabel M. and Schulz H. D. (1998) Deep sulfate reduction completely mediated by anaerobic methane oxidation in sediments of the upwelling area off Namibia. Geochim. Cosmochim. Acta 62, 455-464.

Novosel I., Spence G. D. and Hyndman R. D. (2005) Reduced magnetization produced by increased methane flux at a gas hydrate vent. Mar. Geol. 216, 265-274.

Ohkouchi N., Eglinton T. I., Keigwin L. D. and Hayes J. M. (2002) Spatial and temporal offsets between proxy records in a sediment drift. Science 298, 1224-1227.

Orcutt B. N., Joye S. B., Kleindienst S., Knittel K., Ramette A., Reitz A., Samarkin V., Treude T. and Boetius A. (2010) Impact of natural oil and higher hydrocarbons on microbial diversity, 
distribution, and activity in Gulf of Mexico cold-seep sediments. Deep Sea Res. Part I 57, 2008-2021.

Ortiz J. D., Mix A. C., Rugh W., Watkins J. M. and Collier R. W. (1996) Deep-dwelling planktonic foraminifera of the northeastern Pacific Ocean reveal environmental control of oxygen and carbon isotopic disequilibria. Geochim. Cosmochim. Acta 60, 4509-4523.

Paull C. K., Chanton J. P., Neumann A. C., Coston J. A., Martens C. S. and Showers W. (1992) Indicators of methane-derived carbonates and chemosynthetic organic carbon deposits; examples from the Florida Escarpment. Palaios 7, 361-375.

Paull C. K., Martens C. S., Chanton J. P., Neumann A. C., Coston J., Jull A. J. T. and Toolin L. J. (1989) Old carbon in living organisms and young $\mathrm{CaCO}_{3}$ cements from abyssal brine seeps. Nature 342, 166-168.

Paull C.K. and Ussler W. (2008) Re-evaluating the significance of seafloor accumulations of methane-derived carbonates: seepage or erosion indicators. In Proceedings fo the 6th International Conference on Gas Hydrates (ICGH 2008). pp. 1-12.

Pohlman J. W., Bauer J. E., Canuel E. A., Grabowski K. S., Knies D. L., Mitchell C. S., Whiticar M. J. and Coffin R. B. (2009) Methane sources in gas hydrate-bearing cold seeps: evidence from radiocarbon and stable isotopes. Mar. Chem. 115, 102-109.

Pohlman J. W., Bauer J. E., Waite W. F., Osburn C. L. and Chapman N. R. (2011) Methane hydrate-bearing seeps as a source of aged dissolved organic carbon to the oceans. Nat. Geosci. 4, 37-41.

Pohlman J. W., Knies D. L., Grabowski K. S., DeTurck T. M., Treacy D. J. and Coffin R. B. (2000) Sample distillation/ graphitization system for carbon pool analysis by accelerator mass spectrometry (AMS). Nucl. Instrum. Methods Phys. Res. Sect. B Beam Interact. Mater. Atoms 172, 428-433.

Pohlman J. W., Ruppel C., Hutchinson D. R., Downer R. and Coffin R. B. (2008) Assessing sulfate reduction and methane cycling in a high salinity pore water system in the northern Gulf of Mexico. Mar. Petrol Geol. 25, 942-951.

Raymond P. A. and Bauer J. E. (2001) Riverine export of aged terrestrial organic matter to the North Atlantic Ocean. Nature 409, 497-500.

Reeburgh W. S. (1976) Methane consumption in Cariaco trench waters and sediments. Earth Planet. Sci. Lett. 28, 337-344.

Reeburgh W. S. (2007) Oceanic methane biogeochemistry. Chem. Rev. 107, 486-513.

Reeburgh W.S., Whalen K.A. and Alperin M.J. (1993) The role of methylotrophy in the global methane budget. In Microbial Growth on C-1 Compounds (eds. J. C. Murrell and D. P. Kelley). Interceprt Ltd., Andover, UK. pp. 1-14.

Riedel M., Collett T. S., Malone M. J. and Expedition S. (2006a) Proceedings of the Integrated Ocean Drilling Program Expedition 311. Integrated Ocean Drilling Program, Washington, DC.

Riedel M., Novosel I., Spence G. D., Hyndman R. D., Chapman R. N., Solem R. C. and Lewis T. (2006b) Geophysical and geochemical signatures associated with gas hydrate-related venting in the northern Cascadia margin. Geol. Soc. Am. Bull. 118, 23-38.

Riedel M., Spence G. D., Chapman N. R. and Hyndman R. D. (2002) Seismic investigations of a vent field associated with gas hydrates, offshore Vancouver Island. J. Geophys. Res. Solid Earth 107. http://dx.doi.org/10.1029/2001JB000269.

Riedinger N., Brunner B., Formolo M. J., Solomon E., Kasten S., Strasser M. and Ferdelman T. G. (2010) Oxidative sulfur cycling in the deep biosphere of the Nankai trough, Japan. Geology 38, 851-854.

Ruppel C. (2011) Methane hydrates and contemporary climate change. Nat. Knowledge 2, 1-12.
Sahling H., Rickert D., Lee R. W., Linke P. and Suess E. (2002) Macrofaunal community structure and sulfide flux at gas hydrate deposits from the Cascadia convergent margin, NE Pacific. Mar. Ecol. Prog. Ser. 231, 121-138.

Sivan O., Lazar B., Boaretto E., Yechieli Y. and Herut B. (2004) Radiocarbon in porewater of continental shelf sediments (southeast Mediterranean). Radiocarbon 46, 633-642.

Sommer S., Pfannkuche O., Linke P., Luff R., Greinert J., Drews M., Gubsch S., Pieper M., Poser M. and Viergutz T. (2006) Efficiency of the benthic filter: biological control of the emission of dissolved methane from sediments containing shallow gas hydrates at hydrate ridge. Global Biogeochem. Cycles 20. http:// dx.doi.org/10.1029/2004GB002389.

Spence G. D., Hyndman R. D., Davis E. E. and Yorath C. J. (1991) Seismic structure of the northern Cascadia accretionary prism: evidence from new multichannel seismic reflection data. Geodynamics 22, 257-363.

Stuiver M. and Polach H. A. (1977) Discussion: reporting ${ }^{14} \mathrm{C}$ data. Radiocarbon 19, 355-363.

Stuiver M. and Reimer P. J. (1993) Extended C-14 data-base and revised Calib $3.0 \mathrm{C}-14$ age calibration program. Radiocarbon $35,215-230$.

Suess E. and Whiticar M. J. (1989) Methane-derived $\mathrm{CO}_{2}$ in pore fluids expelled from the Oregon subduction zone. Palaeogeogr. Palaeoclimatol. Palaeoecol. 71, 119-136.

Thomas H., Paull C.K., Caress D.W., Ussler III W., Lundsten E. and Reidel M. (2009) Fine-scale morphology of gas-rich sites on the Cascadia margin near Bullseye vent. American Geophysical Union, AGU, San Francisco.

Torres M. E., McManus J., Hammond D. E., de Angelis M. A., Heeschen K. U., Colbert S. L., Tryon M. D., Brown K. M. and Suess E. (2002) Fluid and chemical fluxes in and out of sediments hosting methane hydrate deposits on Hydrate Ridge, OR, I: hydrological provinces. Earth Planet. Sci. Lett. 201, 525540.

Torres M. E., Mix A. C., Kinports K., Haley B., Klinkhammer G. P., McManus J. and de Angelis M. A. (2003) Is methane venting at the seafloor recorded by ë $13 \mathrm{C}$ of benthic foraminifera shells? Paleoceanography 18. http://dx.doi.org/ 10.1029/2002PA000824.

Trehu A. M., Long P. E., Torres M. E., Bohrmann G., Rack F. R., Collett T. S., Goldberg D. S., Milkov A. V., Riedel M., Schultheiss P., Bangs N. L., Barr S. R., Borowski W. S., Claypool G. E., Delwiche M. E., Dickens G. R., Gracia E., Guerin G., Holland M., Johnson J. E., Lee Y. J., Liu C. S., Su X., Teichert B., Tomaru H., Vanneste M., Watanabe M. and Weinberger J. L. (2004) Three-dimensional distribution of gas hydrate beneath southern Hydrate Ridge: constraints from ODP Leg 204. Earth Planet. Sci. Lett. 222, 845-862.

Treude T., Boetius A., Knittel K., Nauhaus K., Elvert M., Kruger M., Losekann T., Wallmann K., Jorgensen B. B., Widdel F. and Amman R. (2003) Anaerobic oxidation of methane at Hydrate Ridge (OR). Geochim. Cosmochim. Acta 67, A491

Treude T., Niggemann J., Kallmeyer J., Wintersteller P., Schubert C. J., Boetius A. and Jorgensen B. B. (2005) Anaerobic oxidation of methane and sulfate reduction along the Chilean continental margin. Geochim. Cosmochim. Acta 69, 27672779.

Tumey S. J., Grabowski K. S., Knies D. L. and Mignerey A. C. (2004) Radiocarbon data collection, filtering and analysis at the NRL TEAMS facility. Nucl. Instrum. Methods Phys. Res. Sect. B Beam Interact. Mater. Atoms 223-24, 216-220.

Valentine D.L. (2001) Thermodynamic ecology of hydrogen based syntrophy. In Symbiosis: Mechanisms and Model Systems; AOM; hydrogen (ed. J. Seebach). Kluwer Publishers, Dordrecht. 
Valentine D. L., Blanton D. C., Reeburgh W. S. and Kastner M. (2001) Water column methane oxidation adjacent to an area of active hydrate dissociation, Eel River Basin. Geochim. Cosmochim. Acta 65, 2633-2640.

Vogel J. S., Southon J. R., Nelson D. E. and Brown T. A. (1984) Performance of catalytically condensed carbon for use in accelerator mass-spectrometry. Nucl. Instrum. Methods Phys Res. Sect. B-Beam Interact. Mater. Atoms 233, 289-293.

Wellsbury P., Mather I. and Parkes R. J. (2002) Geomicrobiology of deep, low organic carbon sediments in the Woodlark Basin, Pacific Ocean. FEMS Microbiol. Ecol. 42, 59-70.

Westbrook G. K., Thatcher K. E., Rohling E. J., Piotrowski A. M., Palike H., Osborne A. H., Nisbet E. G., Minshull T. A., Lanoiselle M., James R. H., Huhnerbach V., Green D., Fisher R. E., Crocker A. J., Chabert A., Bolton C., BeszczynskaMoller A., Berndt C. and Aquilina A. (2009) Escape of methane gas from the seabed along the West Spitsbergen continental margin. Geophys. Res. Lett. 36.

Whiticar M. J. (1999) Carbon and hydrogen isotope systematics of bacterial formation and oxidation of methane. Chem. Geol. 161, 291-314.
Wood W. T., Gettrust J. F., Chapman N. R., Spence G. D. and Hyndman R. D. (2002) Decreased stability of methane hydrates in marine sediments owing to phase-boundary roughness. Nature 420, 656-660.

Yamamoto S., Alcauskas J. B. and Crozier T. E. (1976) Solubility of methane in distilled water and seawater. J. Chem. Eng. Data 21, 78-80.

Zachos J. C., Rohl U., Schellenberg S. A., Sluijs A., Hodell D. A., Kelly D. C., Thomas E., Nicolo M., R I., Lourens L. J., McCarren H. and Kroon D. (2005) Rapid acidification of the ocean during the Paleocene-Eocene thermal maximum. Science 308, 1611-1615.

Zühlsdorff L. and Spieß V. (2004) Three-dimensional seismic characterization of a venting site reveals compelling indications of natural hydraulic fracturing. Geology 32, 101-104.

Associate editor: Timothy W. Lyons 